\title{
Optimal irrigation planning in river basin development: The case of the Upper Cauvery river basin
}

\author{
S VEDULA \\ Ford India Project, Department of City and Regional Planning, Harvard University, \\ Cambridge, Massachusetts, USA \\ Present address: Department of Civil Engineering, Indian Institute of Science, \\ Bangalore 560012.
}

\begin{abstract}
The study deals with the irrigation planning of the Cauvery river basin in peninsular India which is extensively developed in the downstream reaches and has a high potential for development in the upper reaches. A four-reservoir system is modelled on a monthly basis by using a mathematical programming (LP) formulation to find optimum cropping patterns, subject to land, water and downstream release constraints, and applied to the Cauvery basin. Two objectives, maximizing net economic benefits and maximizing irrigated cropped area, considered in the model are analysed in the context of multiobjective planning and the tradeoffs discussed.
\end{abstract}

Key words. Irrigation planning, multiobjective planning; Cauvery basin; four-reservoir system; Karnataka master plan.

\section{Introduction}

There is an increasing awareness in recent times of a need to evolve comprehensive basin plans for river basin development to meet the national or regional objectives as best as possible. Irrigation has been one of the most important aspects of this planning. Development plans call for improved strategies to conserve water by adopting better and more efficient water management techniques in existing areas and an optimum irrigation planning in those areas proposed to be brought under new irrigation. Linear programming models of various kinds have been used in the past as planning models in river basin development.

The present study concerns the case of the interstate Cauvery river basin in South India. The lower reaches of the basin have excellent irrigation facilities and extensive irrigation has been in practice in these areas since the beginning of the century. Irrigation development in the upper reaches of the basin has been rather slow and restricted by bilateral agreements between the basin states viz. Karnataka, Kerala and Tamil Nadu.

Thus there is a need to extend irrigation facilities to the areas of the upper reaches of the basin subject to providing adequate water supplies to all the areas presently under irrigation in the basin. The present study is based on this hypothesis. An irrigation planning model is formulated for the upper basin (basin above Mettur) to optimize

1. Parts of this paper have been reprinted with permission from the American Geophysical Union: Vedula $S$ and Rogers P P Water Resources Res. 17: 1304-1311, 1981 (C) AGU.

2. A list of symbols is given at the end of the paper. 
crop patterns in the proposed area of development, while meeting the irrigation requirements of the lower basin according to the existing cropping pattern. A linear programming technique was used to find solutions for different objectives. Keeping the proposals made by the Karnataka Master Plan in view, a multi-objective analysis is also made and the implicit trade-off relationships between the different objectives used in planning are determined.

\section{The Cauvery basin}

\subsection{Basin description}

The Cauvery is one of the major interstate rivers of South India. The river rises in the Coorg district of Karnataka, flows in a general south-east direction across the plateau of Karnataka, and after traversing a distance of $400 \mathrm{~km}$ runs along the boundary between Karnataka and Tamil Nadu for $60 \mathrm{~km}$ before entering Tamil Nadu upstream of the Mettur Reservoir (built in 1934). The river then flows through Tamil Nadu for $230 \mathrm{~km}$ before reaching the Grand Anicut, the head of the Delta, and thereafter it divides into a number of branches and finally joins the Bay of Bengal in Tamil Nadu. The total length of the river from its origin to the sea is $800 \mathrm{~km}$. Figure 1 gives a plan of the basin.

The salient features of the basin are given in detail in the Karnataka State Master Plan (1976). The Cauvery has 21 principal tributaries (drainage area of each of which is greater than $250 \mathrm{~km}^{2}$ ). Of these, 9 are located wholly or largely in Karnataka and 12 in Tamil Nadu. The basin has a total drainage area of $81,155 \mathrm{~km}^{2}$ of which $34,273 \mathrm{~km}^{2}$

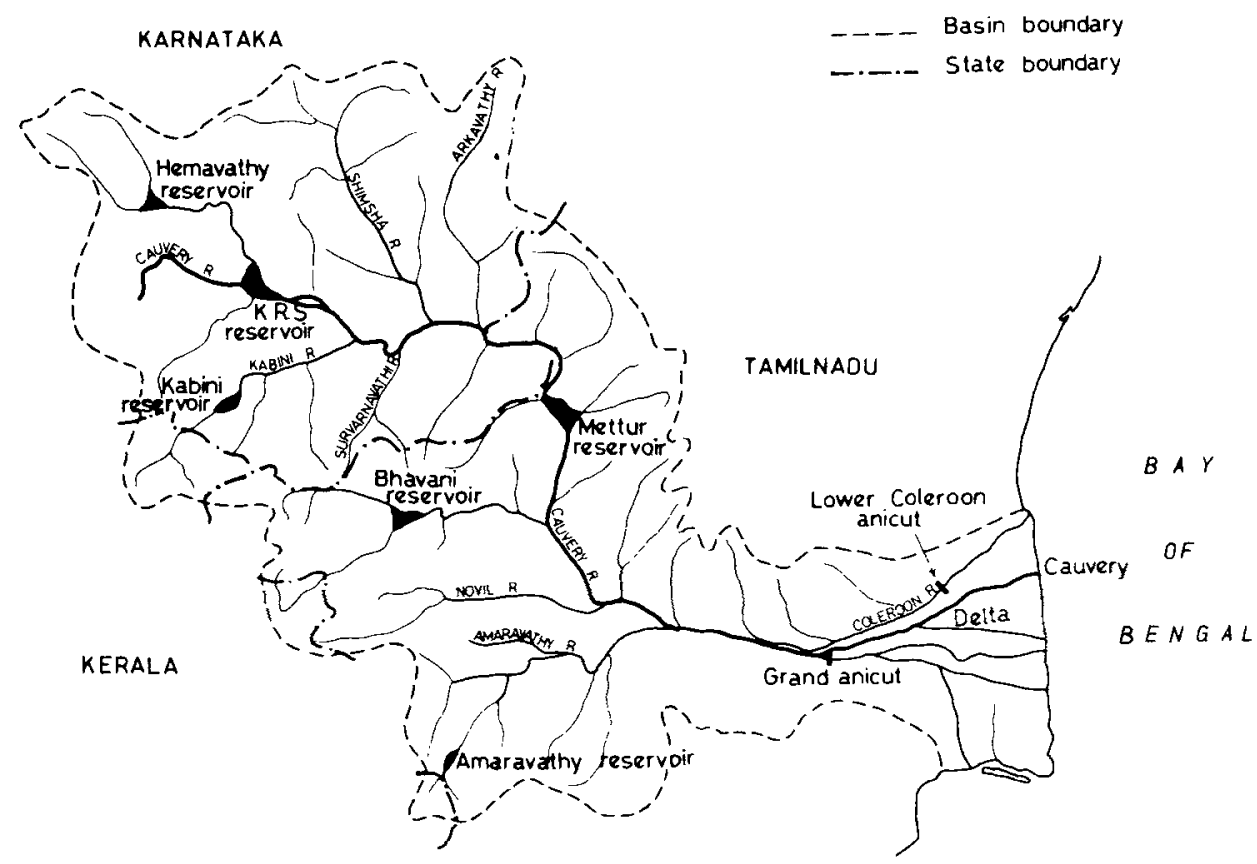

Figure 1. Cauvery basin plan (not to scale). 
$(42.2 \%)$ lies in Karnataka, $2866 \mathrm{~km}^{2}(3.5 \%)$ in Kerala and $44,016 \mathrm{~km}^{2}(54.3 \%)$ in Tamil Nadu.

\subsection{Rainfall}

The basin is under the influence of both the south-west (June to September) and the north-east (October to December) monsoons. The annual rainfall in the basin varies from less than $60 \mathrm{~cm}$ over the north-western part of the Amaravathi sub-basin to more than $600 \mathrm{~cm}$ near the source of the Cauvery River in the extreme west of the basin. The high rainfall however diminishes rapidly eastward. The basin in the east (Lower Coleroon sub-basin and the Delta) has an average annual normal rainfall of about $120 \mathrm{~cm}$. Elsewhere in the basin the annual rainfall is lower than $80-85 \mathrm{~cm}$.

\subsection{Surface water resources}

There are 24 discharge sites on the Cauvery River and its tributaries, of which 8 are on the main river. Fifteen discharge sites are in Karnataka, while 9 are in Tamil Nadu.

The mean annual flows in the Cauvery River at different locations along its course are as follows, the flows indicated being exclusive of consumptive use by upstream irrigation: at Chunchanakatte, $\mathbf{4 8} \mathrm{km}$ upstream of the Krishnaraja Sagara (KRS) dam, $2908 \mathrm{mcu} \mathrm{m}$; at the KRS dam, $5904 \mathrm{mcu} \mathrm{m}$; at Dhanagere Ane, upstream of its confluence with the Shimsha, $8874 \mathrm{~m} \mathrm{cu} \mathrm{m}$; and at Mettur, $9628 \mathrm{~m} \mathrm{cu} \mathrm{m}$.

The net gain (average annual gain) in the river flow in each of the three important reaches is as follows: KRs-Mettur, $2973 \mathrm{~m}$ cu m; Mettur-Grand Anicut, $2690 \mathrm{~m} \mathrm{cu} \mathrm{m}$; and Grand Anicut-Lower Coleroon Anicut, $827 \mathrm{~m}$ cu m.

\subsection{Groundwater resources}

No estimates of groundwater potential are available for the Cauvery basin in Karnataka. However, Karnataka estimated the quantum of deep percolation in its part of the basin as $3936 \mathrm{~m}$ cu m (Master Plan, Part I, page 52) of which a substantial part is supposed to be flowing down to the lower reaches of the basin (in Tamil Nadu). The groundwater development to date has been estimated to be $538 \mathrm{mcu}$ m only. The reason for this low rate of groundwater development is that the area in Karnataka is largely rocky comprising mainly of igneous and metamorphic rocks. However, the geological settings are believed to be quite favourable for groundwater development in the delta region with the thickness of sedimentary formations extending to great depths. The total quantity of replenishable groundwater that can eventually be extracted in the delta, according to UNDP investigations, amounts to about $3650 \mathrm{~m} \mathrm{cu} \mathrm{m}$ per year (Master Plan, Part I, 1976). This is apparently unused at the present time. The total recharge in the non deltaic area in Tamil Nadu is estimated to be $2718 \mathrm{~m} \mathrm{cu} \mathrm{m}$, whereas the groundwater utilization is to the extent of $1954 \mathrm{~m} \mathrm{cu} \mathrm{m}$.

\subsection{Development of irrigation}

Irrigation has been practised in the Cauvery Basin from ancient times, by inundation from delta channels and by tanks and river/anicut channels in the entire basin above the delta.

At the beginning of the 20th century, the aggregate ayacut developed for irrigation was about 700,000 ha out of which nearly 430,000 ha was in the delta. Two major 
reservoirs were constructed in the early thirties on the main river: the KRS reservoir in Karnataka with a live storage of $1269 \mathrm{~m}$ cu $\mathrm{m}$ and the Mettur reservoir in Tamil Nadu with a live storage of $2648 \mathrm{~m}$ cu $\mathrm{m}$. The third major irrigation project on the river is the delta canal irrigation, the canals taking off from the Grand Anicut in Tamil Nadu. Thus by 1971 this aggregate ayacut progressively increased to 840,000 ha. The position in 1971 indicates that Karnataka had irrigation facilities available to $11 \%$ of its culturable area in the basin as against $30 \%$ in Tamil Nadu (table 1). The irrigated cropped area in the basin in 1971 was 1.57 million ha, of which 1.26 million ha was in Tamil Nadu (table 2). Thus irrigation facilities are not evenly distributed over the whole basin.

\subsection{The problem}

One fourth of the people of Karnataka, about $7 \cdot 14$ million, live in the Cauvery Basin, the second largest river basin in the State, covering $18 \%$ of its total area. Almost $2 / 3$ of the basin area in Karnataka State has been identified by the Irrigation Commission (1972) as drought-affected. Thus large areas of the basin with scanty rainfall are starved of irrigation waters in Karnataka, whereas lower downstream the methods of irrigation are old, with the result that a large amount of water is being wasted by going into the sea unutilized. An examination of the withdrawal rates of water for canal irrigation indicates that the withdrawals are far greater than the irrigation requirements

Table 1. Area irrigated in Cauvery basin (ayacuts)

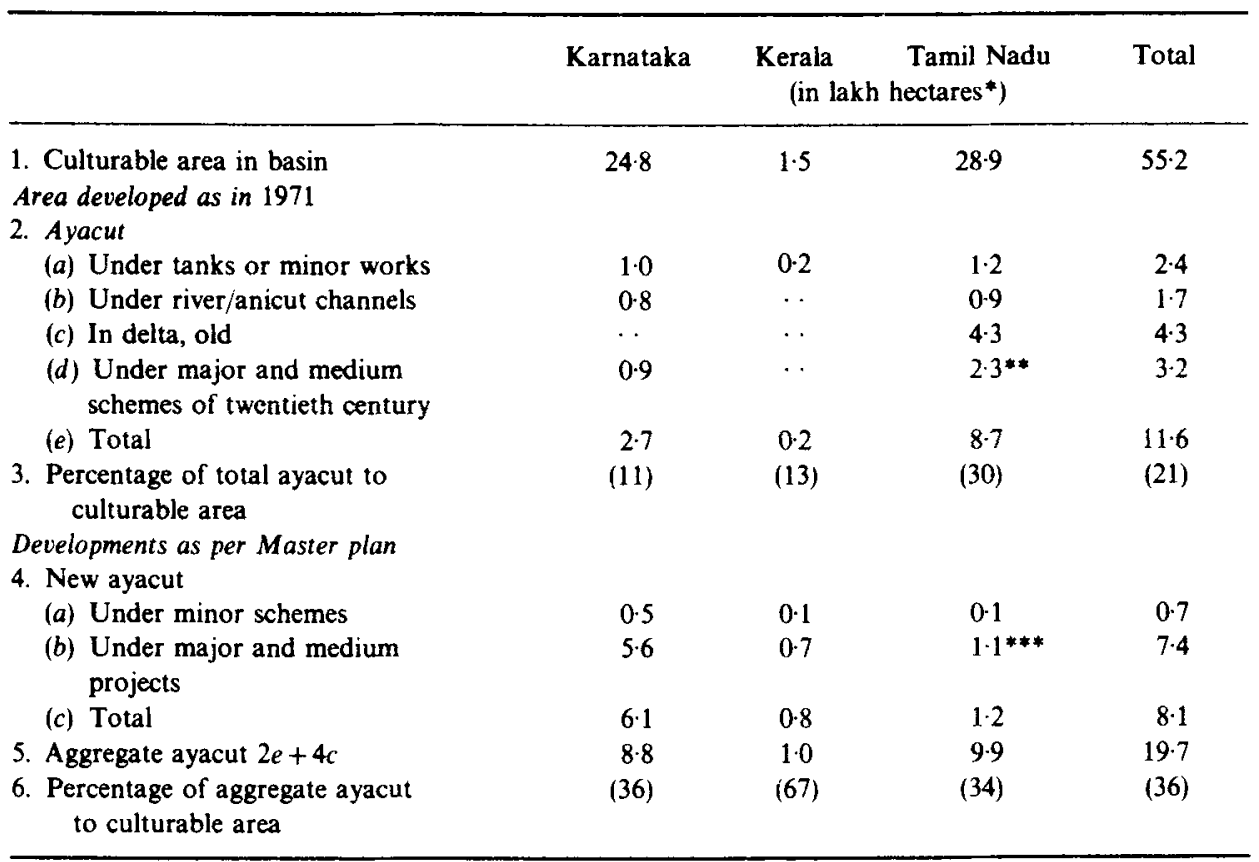

\footnotetext{
Source: Karnataka Master Plan (1976)
}

* except figures in brackets which are percentages, correct to the nearest whole number.

** including 43,700 ha outside the basin developed by Cauvery waters.

*** including 72,500 ha developed by waters imported from outside the basin. 
Table 2. Irrigated cropped areas in Cauvery basin

\begin{tabular}{|c|c|c|c|c|}
\hline \multirow[b]{2}{*}{ 1. Culturable area in basin } & \multirow{2}{*}{ Karnataka } & \multicolumn{2}{|c|}{$\begin{array}{l}\text { Kerala Tamil Nadu } \\
\text { (in lakh hectares) }\end{array}$} & \multirow{2}{*}{$\begin{array}{r}\text { Total } \\
55 \cdot 2\end{array}$} \\
\hline & & $1 \cdot 5$ & $28 \cdot 9$ & \\
\hline \multirow{2}{*}{\multicolumn{5}{|c|}{$\begin{array}{l}\text { Developments as in } 1971 \\
\text { 2. Irrigated cropped area (ICA) }\end{array}$}} \\
\hline & & & & \\
\hline (a) Under tanks or minor works & $\begin{array}{r}1.0 \\
(100)\end{array}$ & $\begin{array}{c}0.3 \\
(150)\end{array}$ & $\begin{array}{r}1 \cdot 2 \\
(100)\end{array}$ & $2 \cdot 5$ \\
\hline (b) Under river/anicut channels & $\begin{array}{r}0.8 \\
(100)\end{array}$ & $\cdots$ & $\begin{array}{r}1.5 \\
(167)\end{array}$ & $2 \cdot 3$ \\
\hline (c) In delta, old & $\cdots$ & $\cdots$ & $\begin{array}{c}7 \cdot 1 \\
(165)\end{array}$ & $7 \cdot 1$ \\
\hline $\begin{array}{l}\text { (d) Under major and medium } \\
\text { schemes of twentieth century }\end{array}$ & $\begin{array}{r}1.0 \\
(111)\end{array}$ & $\cdots$ & $\begin{array}{r}2 \cdot 8 \\
(122)\end{array}$ & $3 \cdot 8$ \\
\hline (e) Total & $\begin{array}{c}2 \cdot 8 \\
(104)\end{array}$ & $\begin{array}{c}0.3 \\
(150)\end{array}$ & $\begin{array}{l}12 \cdot 6 \\
(145)\end{array}$ & $15 \cdot 7$ \\
\hline $\begin{array}{l}\text { Developments as per Master plan } \\
\text { 3. Increased cropped area on }\end{array}$ & \multicolumn{3}{|c|}{ (as in a dependable year) } & \\
\hline 2(b), (c) and (d) above & $\begin{array}{r}2 \cdot 8 \\
(155)\end{array}$ & $\cdots$ & $\begin{array}{c}14.6 \\
(195)\end{array}$ & $17 \cdot 4$ \\
\hline \multicolumn{5}{|l|}{ 4. New cropped area } \\
\hline (a) Under minor schemes & $\begin{array}{r}0.5 \\
(100)\end{array}$ & $\begin{array}{c}0 \cdot 1 \\
(150)\end{array}$ & $\begin{array}{r}0 \cdot 1 \\
(100)\end{array}$ & 0.7 \\
\hline $\begin{array}{l}\text { (b) Under major and medium } \\
\text { projects }\end{array}$ & $\begin{array}{r}7.9 \\
(141)\end{array}$ & $\begin{array}{c}1.4 \\
(200)\end{array}$ & $\begin{array}{r}1 \cdot 4 \\
(127)\end{array}$ & $10 \cdot 7$ \\
\hline 5. Aggregate cropped area & $\begin{array}{l}12 \cdot 2 \\
(139)\end{array}$ & $\begin{array}{c}1 \cdot 8 \\
(180)\end{array}$ & $\begin{array}{l}17 \cdot 3 \\
(175)\end{array}$ & $31 \cdot 3$ \\
\hline
\end{tabular}

(Figures in brackets represent intensity of irrigation over ayacut in per cent)

Source: Karnataka Master Plan (1976)

and that a substantial amount of water is just flowing into the sea. Severe waterlogging and drainage problems have been reported in the downstream reaches and in the delta (Master Plan, Part I, 1976). Development of irrigation in Karnataka had been severely restricted after the construction of the KRS and Mettur reservoirs by a 50 year bilateral agreement between the states of Karnataka and Tamil Nadu, commonly known as the 1924 agreement (which expired in 1974). There has been considerable development in the basin in recent times and consequently the upstream states are demanding a better share of the river waters.

Karnataka took a critical view of the position as it existed in 1971 and proposed a number of developments and new projects in the Master Pian (1976) and also recommended cropping patterns in the whole basin, based on an analysis of rainfall distribution. Tamil Nadu, on the other hand, essentially proposed a modernization of the entire delta system. This is meant to put the waters presently available to more efficient use, alleviate the drainage problems in the delta and bring about better management of the irrigation system as a whole. Negotiations are presently underway for an amicable solution regarding sharing of waters among basin states.

\subsection{The Karnataka Master Plan}

The Karnataka Master Plan divides the entire Cauvery Basin into 16 sub-basins for its 
analysis. The improvement of irrigation envisaged in the plan is shown in tables 1 and 2 . The plan was developed on the premise that only one crop of paddy will be grown in the entire basin (including those areas in Tamil Nadu where extensive double cropping of paddy has been in vogue traditionally for many years). The Master Plan recommends construction of three new reservoirs across the Cauvery river, two in Karnataka and one in the river reach common to Karnataka and Tamil Nadu to gain better control of the waters for irrigation development and to substantially increase the power production. The plan suggests that the cost be shared by the two states appropriately. The details of the plan are contained in the three part publication of the Master Plan (1976).

\subsection{Assumptions in the present study}

There are already a few major storage structures under construction in the upper basin and there is great need for planning the optimum use of the diversions from these reservoirs. It may not be easy to radically change the cropping patterns in areas below Mettur to a single paddy cropping as suggested in the Master Plan. Earlier experience in the Lower Bhavani (Planning Commission 1965) clearly shows the difficulty of adopting the planned cropping patterns in practice. Radical changes in existing cropping patterns which have been in existence for a long time could be expected to be even more difficult to accomplish. This forms one of the working assumptions for the present study. Secondly, the present withdrawals into the canals and the diversions seem to be far greater than the actual requirements in certain areas. Also there is great potential for developing the groundwater resources available in the delta to augment the surface supplies.

\section{The Upper Cauvery Basin Study}

\subsection{Object of the study}

This study aims at bringing out an optimum plan of cropping in the upper basin ensuring adequate supplies for irrigation according to the existing cropping pattern in the lower basin. For the present investigation, the reservoir site at Mettur forms the boundary between the upper basin and the lower basin. This is considered appropriate because (i) most of the proposed new irrigation developments are upstream of Mettur and (ii) Mettur reservoir primarily regulates the flow for downstream irrigation needs along the main river and in the delta.

All major irrigation projects in the upper basin are considered in the study. The activity points for study in the upper basin are the diversions at the four reservoirs: Hemavathy, KRS, Kabini and Mettur (table 3). The water diversion requirements for existing irrigation considered are for those areas presently being irrigated by diversions from the main river. These areas comprise of (i) the delta including the ayacut of the Grand Anicut canal and (ii) the non delta. The non delta area comprises the ayacuts of the Mettur canal, Salem Trichy channels, Kattalai channels, New Kattalai high level canal and Pullambadi canal. It is assumed that the requirements of the Lower Coleroon sub-basin would be met by the river gains between the Grand Anicut-Lower Coleroon Anicut reach and from the groundwater available in the sub-basin. 
Table 3. Reservoir capacities and areas planned for irrigation

\begin{tabular}{llcc}
\hline Status & Reservoir & $\begin{array}{c}\text { Capacity } \\
\text { m cu m }\end{array}$ & $\begin{array}{c}\text { Land area proposed } \\
\text { for irrigation (ha) }\end{array}$ \\
\hline Under construction & Hemavathy & $962 \cdot 77$ & 248,900 \\
Existing & KRs & $1268 \cdot 59$ & $77,900^{*}$ \\
Under construction & Kabini & $453 \cdot 07$ & 87,800 \\
Existing & Mettur & 2647.60 & - \\
\hline
\end{tabular}

* This is in addition to the existing irrigation at KRS reservoir.

\subsection{Features of the study}

Optimum crop patterns in the upper basin are arrived at by an optimization process using a linear programming model for the upper basin. Two systems are formulated: a four-reservoir system consisting of the Hemavathy, kRs, Kabini and Mettur reservoirs and a three-reservoir system consisting of the Hemavathy, KRS and Kabini reservoirs. In the three-reservoir system, the storage at Mettur is not considered and the release from the three-reservoir system is controlled in such a way that the inflows at Mettur are adequate to meet the requirements of the lower basin. For each of the two systems studied, two cases are examined, with and without considering the 'upstream developments'. The 'upstream developments' considered provide for the water requirements of all projects under construction and proposed (in the Master Plan) upstream of KRS reservoir. These include irrigation by storages at (i) Harangi (under construction), and (ii) Votehole, Yagachi, Cauvery reservoir project, Chicklihole and Lakshmanathirtha (proposed). For each of the cases considered above, three objectives viz maximizing (i) the net benefit from agriculture, (ii) the total irrigated cropped area and (iii) the total reservoir diversions are studied. The trade-off relationships between the first two objectives are also discussed.

In all cases, it is ensured that the water available at Mettur is adequate to meet the irrigation requirements of the lower basin as defined earlier on a monthly basis according to the existing cropping pattern. Out of the four major reservoirs in the upper basin, two exist and two are under construction. The Hemavathy and Kabini reservoirs are presently under construction with ayacuts of 248,900 ha and 87,800 ha respectively. The ayacut of the existing KRS reservoir which is presently at 716,600 ha is proposed to be extended by an additional 77,900 ha. The Mettur reservoir supplies water to the Mettur canal which has an ayacut of 18,200 ha.

\subsection{The model}

A twelve season (monthly) linear programming model is formulated for the reservoir system in the upper basin. The input for the deterministic model consists of the mean monthly inflows into the reservoirs, mean monthly evaporation and mean monthly water diversion requirements at existing areas (if any) irrigated by reservoir diversions (KRS and Mettur reservoirs). Two models are formulated, one for the four-reservoir system and another for the three-reservoir system. In the formulation of the model, the reservoirs are represented as $A, B, C$, and $D$ (explained in figure 2). The models have a lot in common. Departures occur in the formulation of constraints which will be mentioned where necessary. The objectives are common for both the models. 


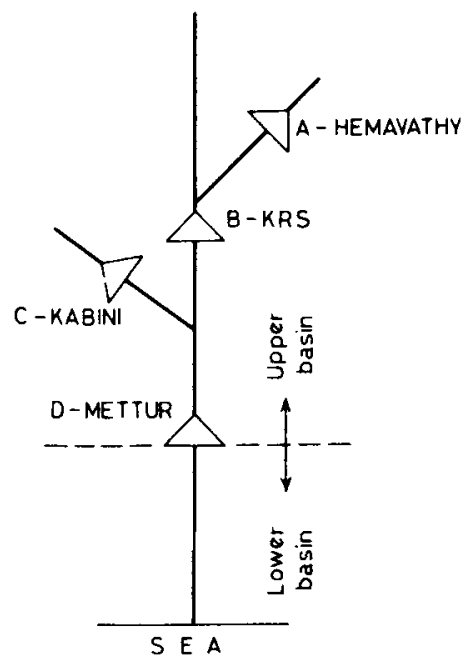

Figure 2. The four-reservoir system of the river basin under study.

3.3a Objective function: Three objective functions are studied.

Objective (1): To maximize the net benefit from all crops

$$
\begin{aligned}
& \max \sum_{i=1}^{M_{j}} \alpha_{i}(I A)_{i}+\sum_{j=1}^{M_{b}} \beta_{j}(I B)_{j}+\sum_{k=1}^{M_{c}} \gamma_{k}(I C)_{k} \\
& +\sum_{u=1}^{N_{j}} \alpha_{u}^{\prime}(U A)_{u}+\sum_{v=1}^{N_{k}} \beta_{v}^{\prime}(U B)_{v}+\sum_{w=1}^{N_{c}} \gamma_{w}^{\prime}(U C)_{w}
\end{aligned}
$$

The model with this objective function considers the options of irrigating or not irrigating any or all of the area available under the command of each reservoir.

Objective (2): Maximize total irrigated cropped area:

$$
\max \sum_{i=1}^{M_{a}}(I A)_{i}+\sum_{j=1}^{M_{k}}(I B)_{j}+\sum_{k=1}^{M_{i}}(I C)_{k} .
$$

Objective (3): Maximize total annual reservoir diversions:

$$
\max \sum_{i=1}^{M_{e}} p_{i}(I A)_{i}+\sum_{j=1}^{M_{b}} q_{j}(I B)_{j}+\sum_{k=1}^{M_{c}} r_{k}(I C)_{k} .
$$

3.3b Constraints: The constraints are discussed below.

(i) Storage-continuity equations: There are 12 equations for each reservoir, one for each month. Each of the equations states that storage at the beginning of a month + total inflow during the month (unregulated inflow plus release from an upstream reservoir, if applicable) - total amount of water diverted to irrigated crops during the month as per their requirement - downstream release during the month - evaporation during the month $\}=$ \{storage at the beginning of the next month $\}$. Thus the storage 
continuity equations for the four reservoirs $A, B, C$ and $D$ for the month $m$ read (after rearrangement) as,

$$
\begin{gathered}
(S A)_{m}-(S A)_{m+1}-\sum_{i=1}^{M_{s}} p_{m, i}(I A)_{m, i}-(R A)_{m}=(E A)_{m}-(F A)_{m} . \\
(S B)_{m}-(S B)_{m+1}+(R A)_{m}-\sum_{j=1}^{M_{b}} q_{m, j}(I B)_{m, j}-(R B)_{m} \\
=(E B)_{m}-(F B)_{m}+(W B)_{m} \\
(S C)_{m}-(S C)_{m+1}-\sum_{k=1}^{M_{c}} \mathrm{r}_{m, k}(I C)_{m, k}-(R C)_{m}=(E C)_{m}-(F C)_{m}, \\
(S D)_{m}-(S D)_{m+1}+(R B)_{m}+(R C)_{m}-(R D)_{m} \\
=(E D)_{m}-(F D)_{m}+(W D)_{m}, m=1,2, \ldots 12
\end{gathered}
$$

The three-reservoir system model will not involve (7) given above.

(ii) Land area constraints: The total cropped area (irrigated and unirrigated) in each month is limited to the land that is in command of each of the reservoirs. There can be a maximum of 12 such constraints for each reservoir. The actual number of constraints depends on the cropping pattern. The constraint for reservoir $A$ in a typical month $m$ is expressed in the form

$$
\sum_{i=1}^{M_{i}}(I A)_{m, i}+\sum_{u=1}^{N_{q}}(U A)_{m, u} \leqslant(L A), \quad m=1,2, \ldots, 12 .
$$

Similarly, the constraints for month $m$ in the case of reservoirs $B$ and $C$ are expressed as

$$
\sum_{j=1}^{M_{b}}(I B)_{m, j}+\sum_{j=1}^{N_{b}}(U B)_{m j} \leqslant(L B), \quad m=1,2, \ldots, 12,
$$

and

$$
\sum_{k=1}^{M_{c}}(I C)_{m, k}+\sum_{k=1}^{N_{c}}(U C)_{m, k} \leqslant(L C), \quad m=1,2, \ldots, 12, \text { respectively. }
$$

In a month where one crop ends and another begins, the area of ending crop is not included in the constraint to permit the possible use of the land for both the crops during different times in that month. No such constraints are needed for reservoir $D$ as there is no new irrigation proposed. The requirements of existing irrigation are accounted for in the storage continuity equations (7) and the only decision variable at reservoir $D$ is the downstream release.

(iii) Downstream release constraints: For a three-reservoir system, the sum of the releases from the reservoirs $B$ and $C$ (KRS and Kabini reservoirs respectively) in each month should not be less than a specified value for that month, i.e.

$$
(R B)_{m}+(R C)_{m} \geqslant(D M)_{m}, \quad m=1,2, \ldots, 12 .
$$

The values $(D M)_{m}$ for $m=1,2, \ldots, 12$ were computed such that if the river flows are maintained at these values, they ensure adequate water supply for existing irrigation in the delta and the non delta areas below Mettur as defined earlier. 
For the four-reservoir system, the storage at reservoir $D$ is also taken into account and the downstream release, $(D D)_{m}$ in each month $m$, is specified as the minimum release to ensure adequate water supply for existing irrigation in the delta and the non delta areas below Mettur as defined. In this case however, the area irrigated by the Mettur canals is not included in the 'non delta' area as their water requirements were accounted for by the term $(W D)_{m}$ in (7). Thus for reservoir $D$, the release constraints are

$$
(R T)_{m} \geqslant(D D)_{m}, \quad m=1,2, \ldots, 12 \text {. }
$$

The values of $(D M)_{m}$ in $(11)$ and $(D D)_{m}$ in (12) were computed from the data as described later.

(iv) Storage capacity constraints: The storage in any month is limited to the capacity (live storage capacity) of the reservoir. For a given month $m(m=1,2,3, \ldots 12)$,

$$
\begin{aligned}
& (S A)_{m} \leqslant(S A)_{\max }, \\
& (S B)_{m} \leqslant(S B)_{\max }, \\
& (S C)_{m} \leqslant(S C)_{\max }, \\
& (S D)_{m} \leqslant(S D)_{\max },
\end{aligned}
$$

where $(S A)_{\max },(S B)_{\max },(S C)_{\max }$ and $(S D)_{\max }$ represent the live storage capacities of reservoirs $A, B, C$ and $D$ respectively.

The decision variables in the model are the cropped areas (irrigated and unirrigated) in the areas commanded by each of the reservoirs $A, B$ and $C$, beginning-of-the month storage and the monthly downstream releases at each of the reservoirs. As the reservoirs are assumed to be operated for irrigation only, the fluctuations of the reservoir level are not considered to pose any problems.

\subsection{Data input to the model}

Most of the data used in this study were either taken directly or computed from the information provided in the Karnataka Master Plan (1976).

3.4a Inflow: The mean monthly unregulated inflows into the four reservoirs (Hemavathy, KRs, Kabini and Mettur) in the upper basin are given in table 4 . These inflows are exclusive of the existing consumptive use upstream of the reservoir sites. The river gain in the KRS-Mettur reach is taken as the unregulated inflow into reservoir $D$ (for modelling) and is given in table 4 . Table 5 gives the estimated mean monthly evaporation at the four reservoirs. The monthly distribution of the total annual evaporation at each reservoir is obtained by proportioning it according to the observed monthly evaporation in the area (Master Plan, appendix V, p. 30, statement 1).

3.4b Cropping and crop water requirements: There are 12 principal crops proposed (in the Master Plan) to be grown in the areas commanded by reservoir $A$ (Hemavathy Reservoir), 10 crops by reservoir $B$ (KRS Reservoir extension) and 14 by reservoir $C$ (Kabini). The model exercises the option of irrigating or not irrigating any or all of these crops depending on the objective used. Table 6 lists the crops considered for irrigation from reservoir $A$, table 8 shows those from reservoir $B$ and table 10 from reservoir $C$. Tables 7, 9 and 11 list the unirrigated crops considered for cropping by reservoirs $A, B$ and $C$ respectively, with the growing months for each indicated by the symbol $x$. These are the same crops as the irrigated crops listed earlier in tables 6,8 and 10 where the 
Table 4. Mean monthly inflows (unregulated) into the reservoirs (in $\mathbf{m}$ cu $\mathbf{m}$ )

\begin{tabular}{|c|c|c|c|c|}
\hline \multirow[b]{2}{*}{$\begin{array}{l}\text { Month } \\
m \\
(1)\end{array}$} & \multicolumn{4}{|c|}{ Reservoir } \\
\hline & $\begin{array}{c}A \\
(F A)_{m} \\
(2)\end{array}$ & $\begin{array}{c}B \\
(F B)_{m} \\
(3)\end{array}$ & $\begin{array}{c}C \\
(F C)_{m} \\
(4)\end{array}$ & $\begin{array}{c}D \\
(F D)_{m} \\
(5)\end{array}$ \\
\hline June & $109 \cdot 13$ & 254.49 & $256 \cdot 2$ & -1.7 \\
\hline July & $716 \cdot 10$ & 1552.56 & $997 \cdot 7$ & $77 \cdot 3$ \\
\hline August & $566 \cdot 79$ & $1121 \cdot 51$ & $714 \cdot 0$ & $360 \cdot 3$ \\
\hline September & $238 \cdot 41$ & $407 \cdot 29$ & $303 \cdot 0$ & $495 \cdot 2$ \\
\hline October & 255.85 & $325 \cdot 31$ & $257 \cdot 1$ & $884 \cdot 6$ \\
\hline November & $98 \cdot 81$ & $101 \cdot 13$ & $131 \cdot 6$ & 471.9 \\
\hline December & $44 \cdot 18$ & 53.81 & $64 \cdot 6$ & $282 \cdot 6$ \\
\hline January & $25 \cdot 61$ & 35.09 & 35.8 & $109-2$ \\
\hline February & 15.92 & $26 \cdot 39$ & $27 \cdot 0$ & $25-8$ \\
\hline March & $12 \cdot 25$ & $15 \cdot 00$ & $21 \cdot 8$ & $17 \cdot 9$ \\
\hline April & 11.99 & $23 \cdot 25$ & $28 \cdot 2$ & $47 \cdot 2$ \\
\hline \multirow[t]{2}{*}{ May } & $28 \cdot 20$ & $49 \cdot 27$ & 59.9 & $194 \cdot 1$ \\
\hline & $2124 \cdot 23$ & $3965 \cdot 10$ & 2896.9 & $2964 \cdot 4$ \\
\hline
\end{tabular}

(2): Average of 38 years; (3): Average of 35 years at reservoir $B$ - value at (2); (4): Average of 38 years; (5): Net river gain above reservoir $D$ and below reservoirs $B$ and $C$ (Average of 38 years)

Table 5. Estimated monthly reservoir evaporation losses (in $\mathrm{m}$ cu $\mathrm{m}$ )

\begin{tabular}{|c|c|c|c|c|}
\hline \multirow{3}{*}{$\begin{array}{l}\text { Month } \\
m\end{array}$} & \multicolumn{4}{|c|}{ Reservoir } \\
\hline & $A$ & $\boldsymbol{B}$ & $C$ & $D$ \\
\hline & $(E A)_{m}$ & $(E B)_{m}$ & $(E C)_{m}$ & $(E D)_{m}$ \\
\hline June & $8 \cdot 2$ & $12 \cdot 9$ & 8.0 & $15 \cdot 4$ \\
\hline July & 7.0 & $11 \cdot 1$ & 6.9 & 13.9 \\
\hline August & 6.9 & $10 \cdot 8$ & 6.6 & $13 \cdot 3$ \\
\hline September & $6 \cdot 2$ & $9 \cdot 7$ & 6.0 & 13.7 \\
\hline October & 6.6 & $10 \cdot 3$ & $6 \cdot 4$ & $11 \cdot 3$ \\
\hline November & $6 \cdot 2$ & 9.7 & 60 & $9 \cdot 1$ \\
\hline December & $7 \cdot 2$ & 11.4 & $7 \cdot 0$ & $9 \cdot 0$ \\
\hline January & 8.5 & 13.4 & $8 \cdot 3$ & 10.7 \\
\hline February & 9.6 & $15 \cdot 1$ & $9 \cdot 3$ & 11.9 \\
\hline March & $12 \cdot 6$ & $19 \cdot 6$ & $12 \cdot 2$ & $14 \cdot 7$ \\
\hline April & $11 \cdot 3$ & 17.8 & $11 \cdot 0$ & $13 \cdot 2$ \\
\hline \multirow[t]{2}{*}{ May } & $8 \cdot 8$ & 13.9 & $8 \cdot 6$ & 13.8 \\
\hline & $\overline{99 \cdot 1}$ & $\overline{155 \cdot 7}$ & $96 \cdot 3$ & $\overrightarrow{150.0}$ \\
\hline
\end{tabular}

monthly water diversion requirements for irrigation are given during the growing months for each crop.

Monthly crop water requirements were computed based on the guidelines given by the Water Technology Division of the Indian Council of Agricultural Research (1971). (Minor modifications were introduced to facilitate computations on a computer in 


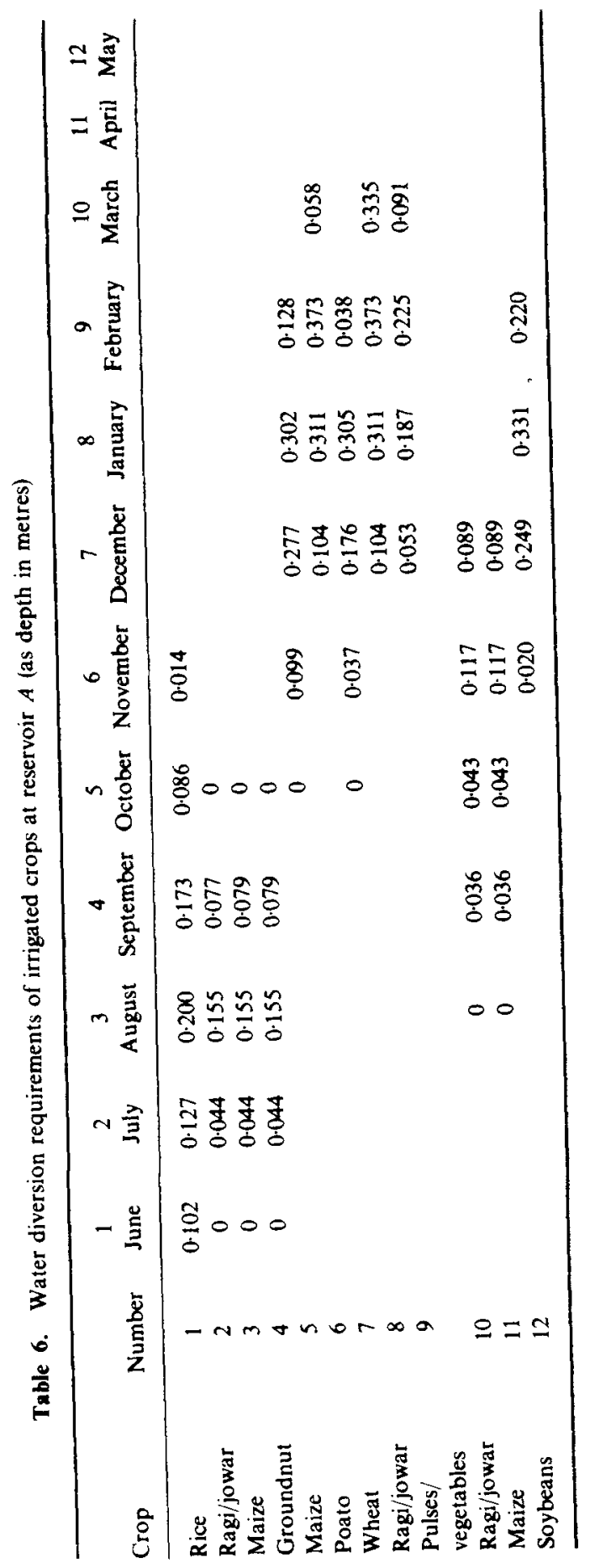


respect of averaging the water requirements during a month). Net irrigation requirements of all crops proposed to be grown in all projects (under construction and proposed) in the upper basin were computed taking into account the crop consumptive use and the effective rainfall in the area. In the case of the KRS reservoir, irrigation requirements of existing and proposed (extension) ayacuts were computed as required by the data input to the model. Farm losses are assumed to be $30 \%$ and a conveyance efficiency of $70 \%$ is assumed. Thus the water diversion requirements (WDR) at the reservoir is twice the net irrigation requirement (NIR) at the farm. The actual crops and the crop periods are chosen according to the proposals of the Karnataka Master Plan at each of the ayacuts. The computed crop water diversion requirements at the Hemavathy, KRS and Kabini reservoirs are given in tables 6,8 and 10 respectively. The water diversion requirements for existing irrigation at the KRS and Mettur reservoirs are given in table 12.

3.4c Crop water requirements for areas below Mettur An estimate is made of the monthly water diversion requirements for existing irrigated areas in the delta and the non-delta areas downstream of Mettur. Only those areas that are irrigated by diversions from the main river are considered. The non-delta areas comprise those areas irrigated by (i) Salem-Trichy channels (ii) Kattalai channels (iii) New Kattalai high level canal (iv) Pullambadi canal and (v) Mettur canal. The delta area is taken to include the ayacut of the Grand Anicut canal.

The total annual water diversion requirements for existing irrigation in the Lower Coleroon sub-basin were estimated at $483.6 \mathrm{~m} \mathrm{cu} \mathrm{m}$, whereas the average river gain in the reach between the Grand Anicut and the Lower Coleroon Anicut is $827 \mathrm{~m} \mathrm{cu} \mathrm{m}$. The Master Plan (appendix V, p. 105) estimates that the groundwater potential in the subbasin is $651 \mathrm{~m}$ cu $\mathrm{m}$. For these reasons, it is assumed in the present study that the Lower Coleroon sub-basin does not require any releases from the upstream areas other than the unregulated river flow into the sub-basin.

The minimum downstream release requirements at Mettur reservoir for the fourreservoir system were obtained by summing up the total water diversion requirements for the lower basin (delta and non-delta excluding the Mettur canal area) and deducting the river gain in the Mettur-Grand Anicut reach. The requirement is set at zero in those months when the river gain is greater than the diversion requirement. The monthly releases computed thus, $(D D)_{m}$, are shown in table 13 .

In the case of the three-reservoir system, the minimum sum of the releases from the KRS and Kabini reservoirs has to be specified for each month. To work it out, first the water diversion requirements of the delta and non-delta areas are summed up. The river gain between the Mettur-Grand Anicut reach is deducted from this, rounding off the negative values to zeros. This then gives the inflow requirement at Mettur. The average river gain between KRS and Mettur is deducted from this next, again rounding the negative values to zeros. The monthly releases computed thus, $(D M)_{m}$, are also shown in table 13.

3.4d Effect of 'upstream developments' on river inflows A modification of the inflows given in table 4 is necessary when the proposed 'upstream developments' are taken into account. The computations of water diversion requirements at the projects Yagachi, Harangi, Votehole, Lakshmanathirtha, Chicklihole, and the Cauvery reservoir project, revealed that the annual inflow into the KRS reservoir and into the Hemavathy reservoir would be reduced by $19.7 \%$ and $5.7 \%$ respectively. The monthly inflows into the KRS 


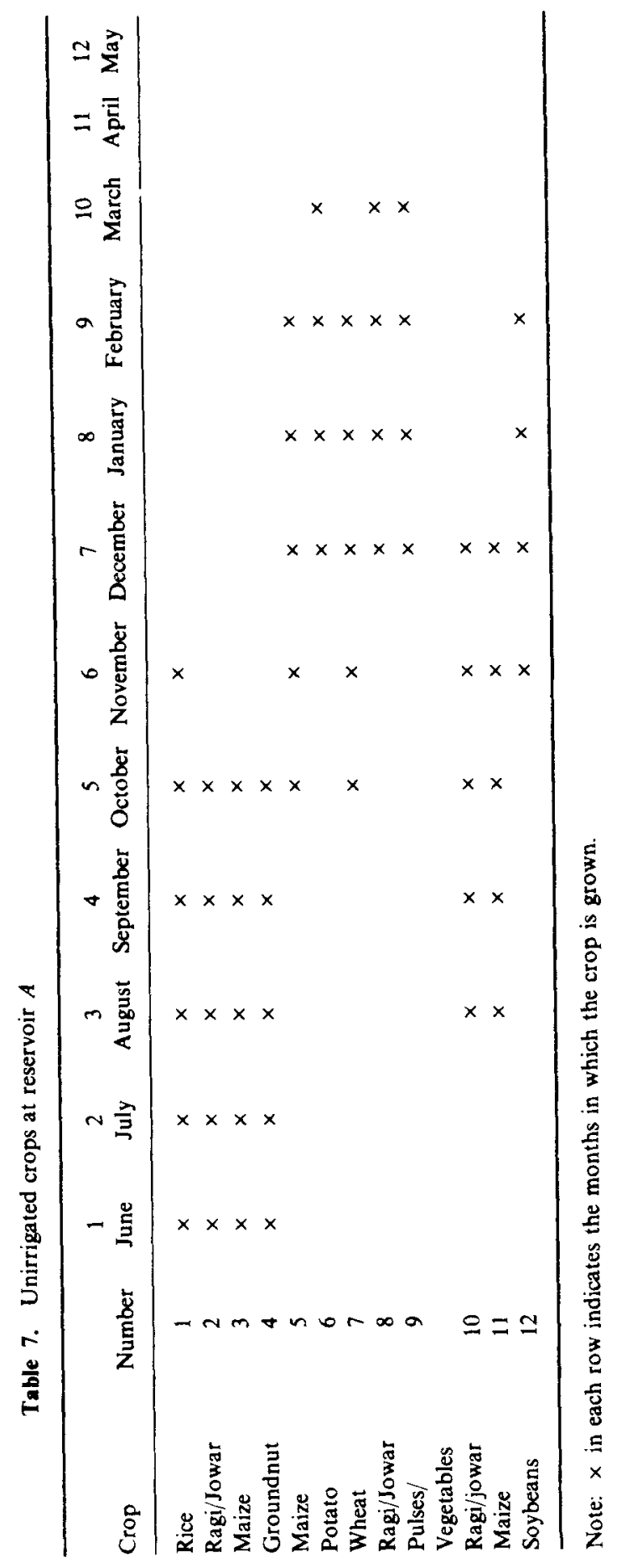




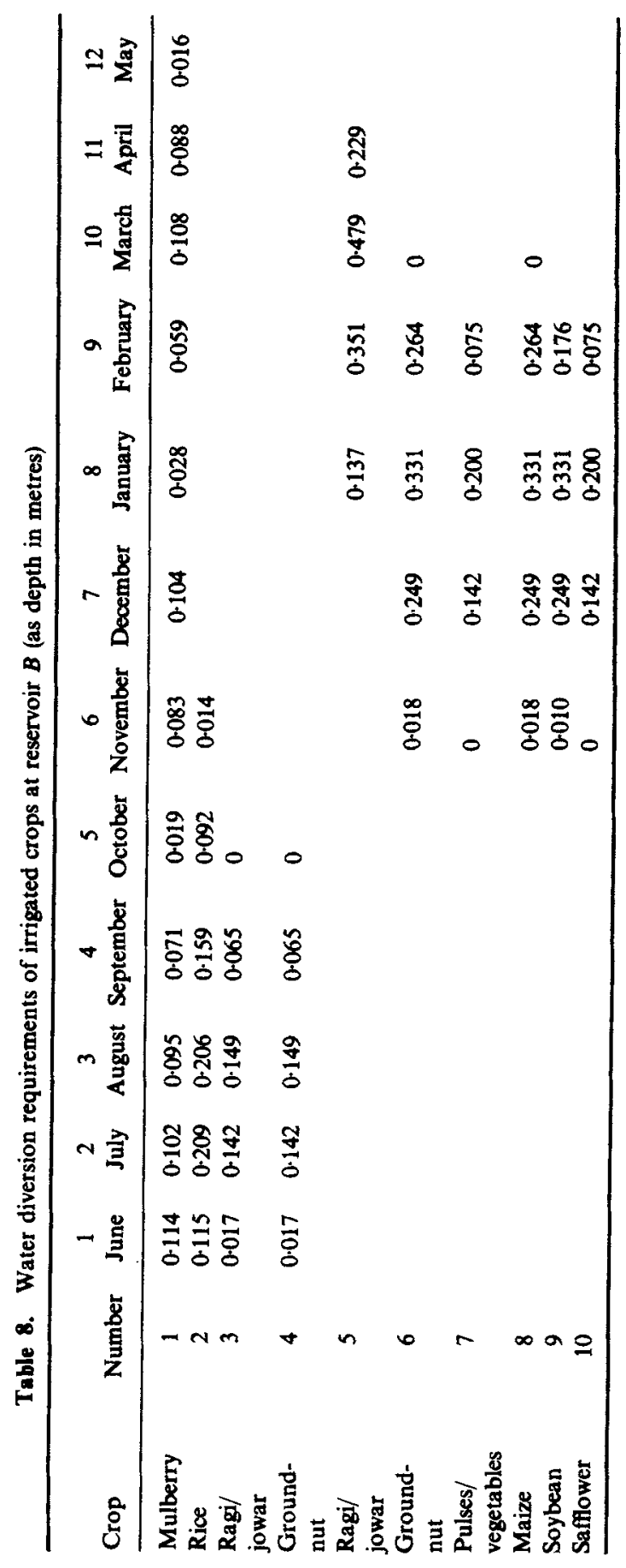




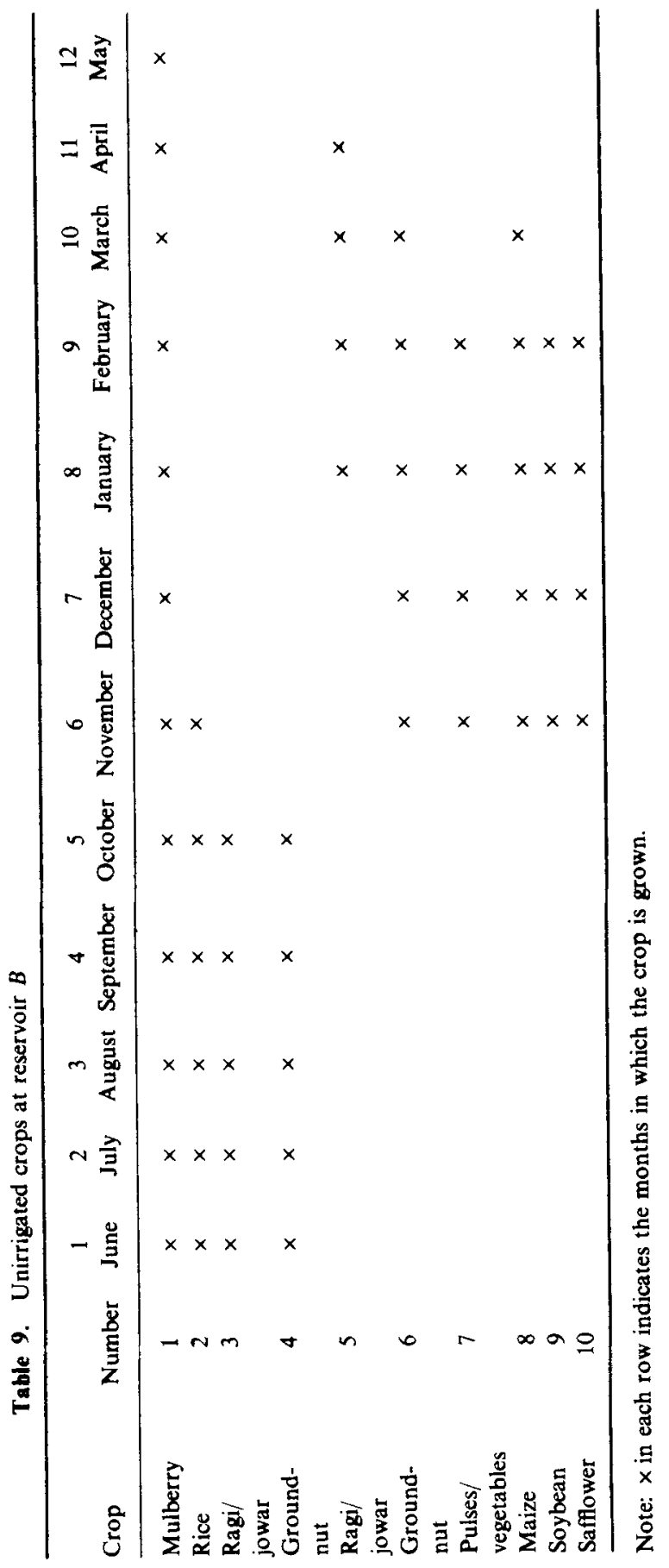




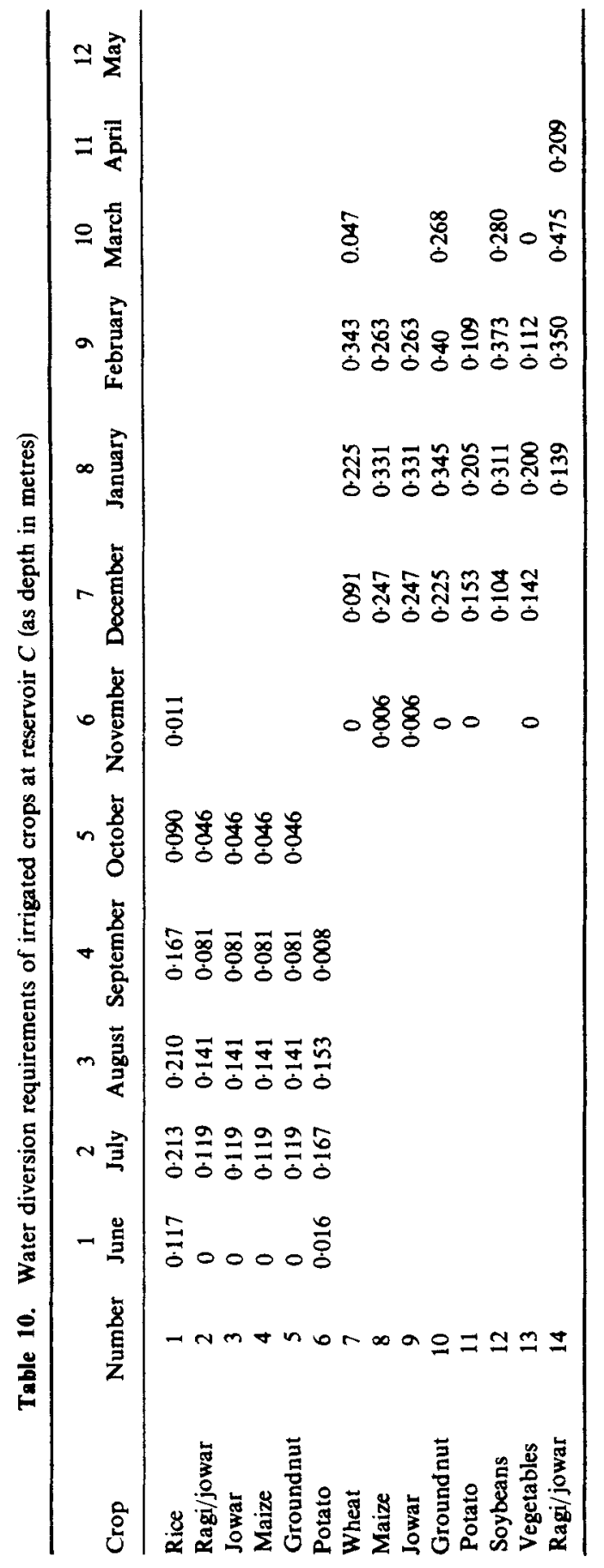


Table 11 Unirrigated crops at reservoir $C$

\begin{tabular}{|c|c|c|c|c|c|c|c|c|c|c|c|c|c|}
\hline Crop & $\begin{array}{l}\text { Num- } \\
\text { ber }\end{array}$ & $\begin{array}{c}1 \\
\text { June }\end{array}$ & $\begin{array}{c}2 \\
\text { July }\end{array}$ & $\begin{array}{c}3 \\
\text { Aug- } \\
\text { ust }\end{array}$ & $\begin{array}{c}4 \\
\text { Septem- } \\
\text { ber }\end{array}$ & $\begin{array}{c}5 \\
\text { Octo- } \\
\text { ber }\end{array}$ & $\begin{array}{c}6 \\
\text { Novem- } \\
\text { ber }\end{array}$ & $\begin{array}{c}7 \\
\text { Decem- } \\
\text { ber }\end{array}$ & $\begin{array}{c}8 \\
\text { Janu- } \\
\text { ary }\end{array}$ & $\begin{array}{c}9 \\
\text { Febru- } \\
\text { ary }\end{array}$ & $\begin{array}{c}10 \\
\text { March }\end{array}$ & $\begin{array}{c}11 \\
\text { April }\end{array}$ & $\begin{array}{c}12 \\
\text { May }\end{array}$ \\
\hline Rice & 1 & $x$ & $x$ & $x$ & $x$ & $x$ & $x$ & & & & & & \\
\hline $\begin{array}{l}\text { Ragi/ } \\
\text { jowar }\end{array}$ & 2 & $x$ & $x$ & $x$ & $x$ & $x$ & & & & & & & \\
\hline Jowar & 3 & $x$ & $x$ & $x$ & $x$ & $x$ & & & & & & & \\
\hline Maize & 4 & $x$ & $x$ & $x$ & $x$ & $x$ & & & & & & & \\
\hline $\begin{array}{l}\text { Ground- } \\
\text { nut }\end{array}$ & 5 & $x$ & $x$ & $x$ & $x$ & $x$ & & & & & & & \\
\hline Potato & 6 & $x$ & $x$ & $x$ & $x$ & & & & & & & & \\
\hline Wheat & 7 & & & & & & $x$ & $x$ & $x$ & $x$ & $x$ & & \\
\hline Maize & 8 & & & & & & $x$ & $x$ & $x$ & $x$ & & & \\
\hline Jowar & 9 & & & & & & $x$ & $x$ & $x$ & $x$ & & & \\
\hline $\begin{array}{l}\text { Ground- } \\
\text { nut }\end{array}$ & 10 & & & & & & $x$ & $x$ & $x$ & $x$ & $x$ & & \\
\hline Potato & 11 & & & & & & $x$ & $x$ & $x$ & $x$ & & & \\
\hline Soybeans & 12 & & & & & & & $x$ & $x$ & $x$ & $x$ & & \\
\hline Vegetables & 13 & & & & & & $x$ & $x$ & $x$ & $x$ & & & \\
\hline $\begin{array}{l}\text { Ragi/ } \\
\text { jowar }\end{array}$ & 14 & & & & & & & & $x$ & $x$ & $x$ & $x$ & \\
\hline
\end{tabular}

Note: $x$ in each row indicates the months in which the crop is grown.

Table 12 Water diversion requirements at existing reservoirs in $\mathrm{mcu} \mathbf{m}$.

\begin{tabular}{lrllll}
\hline & \multicolumn{2}{c}{ Reservoir } & & \multicolumn{2}{c}{ Reservoir } \\
Month & $B$ & $D^{*}$ & Month & $B$ & $D^{*}$ \\
\hline June & $82 \cdot 4$ & 0 & December & $32 \cdot 2$ & $4 \cdot 4$ \\
July & $149 \cdot 0$ & $31 \cdot 2$ & January & $50 \cdot 2$ & 0 \\
August & $134 \cdot 6$ & $50 \cdot 0$ & February & $58 \cdot 8$ & 0 \\
September & $95 \cdot 6$ & $56 \cdot 0$ & March & $59 \cdot 2$ & 0 \\
October & $52 \cdot 8$ & $30 \cdot 4$ & April & $18 \cdot 2$ & 0 \\
November & $24 \cdot 2$ & $26 \cdot 0$ & May & $5 \cdot 2$ & 0 \\
\hline
\end{tabular}

* Mettur canal paddy sowing in mid-July

Table 13 Minimum monthly downstream releases (computed in $\mathrm{m}$ cu m)

\begin{tabular}{lcclcc}
\hline Month & $\begin{array}{c}\text { Four-reservoir } \\
\text { system }\end{array}$ & $\begin{array}{c}\text { Three-reservoir } \\
\text { system }\end{array}$ & Month & $\begin{array}{c}\text { Four-reservoir } \\
\text { system* }\end{array}$ & $\begin{array}{c}\text { Three-reservoir } \\
\text { system * * }^{*}\end{array}$ \\
\hline June & $570 \cdot 0$ & $610 \cdot 47$ & December & 0 & 0 \\
July & $166 \dot{8} \cdot 5$ & 1719.22 & January & $329 \cdot 2$ & $220 \cdot 04$ \\
August & 1360.8 & $1061 \cdot 47$ & February & $569 \cdot 5$ & $543 \cdot 73$ \\
September & $775 \cdot 9$ & $308 \cdot 30$ & March & 708.6 & $690 \cdot 73$ \\
October & 0 & 0 & April & 140.0 & 64.95 \\
November & 0 & 0 & May & 0 & 0 \\
\hline
\end{tabular}

* release from Mettur reservoir

** total release from the KRS and Kabini reservoirs, Mettur canal paddy sowing in mid-June 
and Hemavathy reservoirs given in table 4 were thus reduced by $19.7 \%$ and $5.7 \%$ respectively and the modified inflows were then used as the input to the model in those studies which included the effect of upstream development.

3.4e Net benefits from crops Estimates of net benefit per unit area of irrigated and unirrigated crops are given in table 14. The gross income was computed at the wholesale price of the crop produce and from representative values of crop yield per hectare for the region under study. The only cost of inputs deducted to estimate net benefits is of fertilizers. The dosage of fertilizers is assumed at the optimum value to give maximum yield (Parikh \& Srinivasan 1974). All other costs such as labour, pesticides, insecticides and cost of water were not deducted. Thus net benefit, as used in this study, is the gross income less the cost of fertilizer only.

\subsection{Cases studied and their solutions}

The computer solutions were obtained using a MPSX linear programming package on the IBM 370/168 system at Harvard University, Cambridge, Massachusetts. In all runs, the value of $(I B)_{1}$, the irrigated area for crop 1 (mulberry) at the krsreservoir, was fixed at 20,700 hectares as proposed in the Karnataka Master Plan. This was done because of the growing demand for the mulberry leaves for sericulture in Karnataka which produces $82 \%$ of the total mulberry silk in the country (Report of the National Commission on Agriculture, 1976). The net benefits arrived at in all the solutions exclude those associated with the fixed mulberry cropping.

The following are the various cases considered for detailed analysis, and the table numbers are also given in brackets for reference to their detailed solution: $4 Y N(15) ; 4 Y I$ (16); 4YD (17); 4NN (18); 4NI (19); 4ND (20); 3YN (21); 3YI (22); 3YD (23); 3NN (24); 3NI (25); $3 N D$ (26); where 3 and 4 in the first place indicate a three-and a four-reservoir system, respectively; $Y$ and $N$ in the second place indicate that "upstream developments" were considered and not considered, respectively; $N, I$ and $D$ in the third place maximize total net benefits, total irrigated cropped area and total reservoir diversions, respectively.

\section{Results and discussion}

The results of all cases analysed in respect of the four-reservoir system are summarised below.

$\begin{array}{lccc}\text { Case } & \begin{array}{c}\text { Net benefits } \\ \left(10^{6} \mathrm{Rs}\right)\end{array} & \begin{array}{c}\text { Irigated cropped } \\ \text { area } \\ (100 \mathrm{ha})\end{array} & \begin{array}{c}\text { Total diversion } \\ (\mathrm{m} \text { cu m) }\end{array} \\ 4 Y N & 2084.709 & 527,570 & 3463.88 \\ 4 Y I & 1659.623 & 755,600 & 3540.15 \\ 4 Y D & 1738.194 & 666,061 & 3994.09 \\ 4 N N & 2124.313 & 621,860 & 4365.90 \\ 4 N I & 1809.500 & 756,680 & 4516.80 \\ 4 N D & 2008.316 & 688,090 & 4767.30\end{array}$

It may be noted that the maximum net benefits for the four-reservoir system increase by only $2 \%$ when the upstream developments are not considered. This is because the inflows into the kRS reservoir are not affected significantly by considering upstream 
developments, as a large portion of the infiow consists of unregulated flow above the reservoir. There is practically no change in the maximum irrigated cropped area between the two cases $4 Y I$ and $4 N I$ indicating that the optimal plan for the water use for the four-reservoir system is practically independent of the existing and proposed upstream developments. The locations of these developments are so far ahead of the major reservoirs in the upper basin that their consideration has little effect on the optimum values of the objectives attained. The optimum total diversion, however, changes by nearly $20 \%$ between the cases $4 Y D$ and $4 N D$.

The optimum cropping patterns for different cases considered in the four-reservoir system are presented in tables 15 through 20 . Tables 15 to 17 contain results of the runs with 'upstream developments' and tables 18 to 20 without these. The results of the run $4 Y N$ (table 15) give the solution for maximizing net benefits in the case in which it is assumed that there is no change in the existing cropping pattern in the upper or the lower basin. All projects existing, under construction and proposed are taken into

Table 14 Estimated net benefits of crops

\begin{tabular}{lcclrr}
\hline Crop & \multicolumn{2}{c}{$\begin{array}{c}\text { Net benefits* } \\
\text { Irrigated }\end{array}$} & Unirrigated & Crop & \multicolumn{2}{c}{ Net benefits (Rs/ha) } \\
& & 1525 & Potato & 2500 & 2380 \\
Rice & 2950 & 1450 & Wheat & 1900 & 825 \\
Ragi/jowar & $2450^{* *}$ & 1300 & Soybeans & 2800 & 1300 \\
Maize & 2300 & 1100 & Pulses/vegetables & 600 & 360 \\
Groundnut & 2400 & & & & \\
\hline
\end{tabular}

- Net benefits are obtained by deducting the estimated cost of fertilizer from the produce value at wholesale prices (at 1970-72 levels) ** Rs 3200 used for runs with the three-reservoir system.

Table 15. Solution for maximum net benefits*

Maximum net benefits $=$ Rs $2.1 \times 10^{3}$ million; Total diversion $=3463.88 \mathrm{~m} \mathrm{cu} \mathrm{m}$; Total irrigated cropped area $=527,570$ ha.

\begin{tabular}{lcc}
\hline Crop $\quad$ Season & $I / U \quad \begin{array}{c}\text { Cropped area } \\
(100 \mathrm{ha})\end{array}$ \\
\hline
\end{tabular}

\section{Diversion from Hemavathy reservoir}

$\begin{array}{ll}\text { Rice } & \text { June-November } \\ \text { Ragi/jowar } & \text { June-October } \\ \text { Soybeans } & \text { November-February }\end{array}$

Potato December-March

$\begin{array}{lrl}I & 1244.5 & \\ I & 1244.5 & \\ I & 557.7 & C I=2.0 \\ U & 1931 \cdot 3 & I I=1.22\end{array}$

Diversion from KRS reservoir

$\begin{array}{llllr}\text { Mulberry } & \text { Perennial } & I & 207.0 & C I=1.73 \\ \text { Rice } & \text { June-November } & I & 572.0 & I I=1.73 \\ \text { Soybeans } & \text { November-February } & I & 572.0 & \end{array}$

Diversion from Kabini reservoir

\begin{tabular}{lllll} 
Rice & June-November & $I$ & 878.0 & $C I=2 \cdot 0$ \\
Potato & November-February & $U$ & 878.0 & $I I=1 \cdot 0$ \\
\hline
\end{tabular}

* Exclusive of mulberry cropping fixed at $20,700 \mathrm{ha} ; \quad I=$ irrigated, $U=$ unirrigated; $C I=$ cropping intensity; $I I=$ irrigation intensity. 
Table 16. Solution for maximum irrigated cropped area-case $4 Y I$

Maximum irrigated cropped area $=755,600 \mathrm{ha}$; Total diversion $=3540 \cdot 151 \mathrm{~m} \mathrm{cu} \mathrm{m}$; Total net benefits (excluding mulberry) $=\mathbf{R s ~} 1.7 \times 10^{3}$ million.

\begin{tabular}{|c|c|c|c|c|}
\hline Crop & Season & $I / U$ & $\begin{array}{l}\text { ropped area } \\
\text { (100 ha) }\end{array}$ & \\
\hline \multicolumn{5}{|c|}{ Diversion from Hemavathy reservoi: } \\
\hline Rice & June-November & $I$ & $264 \cdot 5$ & \\
\hline Maize & June-October & $I$ & $492 \cdot 1$ & \\
\hline Groundnut & June-October & $I$ & $1732 \cdot 4$ & \\
\hline Wheat & October-February & $I$ & $1960-0$ & $C I=2 \cdot 0$ \\
\hline Potato & December-March & $U$ & $529 \cdot 0$ & $I I=1.79$ \\
\hline \multicolumn{5}{|c|}{ Diversion from $\mathrm{KRS}$ reservoir } \\
\hline Mulberry & Perennial & $I$ & $207 \cdot 0^{*}$ & \\
\hline Groundnut & June-October & $I$ & $572 \cdot 0$ & \\
\hline Pulses/Vegetables & November-February & $I$ & $108 \cdot 7$ & $C I=1.73$ \\
\hline Soybeans & November-February & $I$ & 463.3 & $I I=1.73$ \\
\hline \multicolumn{5}{|c|}{ Diversion from Kabini reservoir } \\
\hline Rice & June-November & $I$ & 260.6 & \\
\hline Ragi/jowar & June-October & $I$ & $617 \cdot 4$ & $C I=2 \cdot 0$ \\
\hline \multicolumn{5}{|l|}{ Vegetables and } \\
\hline minor crops & November-March & $I$ & $878 \cdot 0$ & $I I=2 \cdot 0$ \\
\hline
\end{tabular}

$I=$ irrigated, $U=$ unirrigated; $C I=$ cropping intensity; $I I=$ irrigation intensity; * fixed value

Table 17. Solution for maximum total diversion-case 4YD

Maximum reservoir diversion $=3994.092 \mathrm{~m}$ cu m ; Total irrigated cropped area $=666,061 \mathrm{ha}$; Total net benefits (excluding mulberry) $=\mathrm{Rs} 1.7 \times 10^{3}$ million

\begin{tabular}{|c|c|c|c|c|}
\hline Crop & Season & $I / U$ & $\begin{array}{l}\text { topped area } \\
(100 \text { ha) }\end{array}$ & \\
\hline \multicolumn{5}{|c|}{ Diversion from Hemavathy reservoir } \\
\hline $\begin{array}{l}\text { Maize } \\
\text { Maize } \\
\text { Wheat } \\
\text { Potato }\end{array}$ & $\begin{array}{l}\text { June-October } \\
\text { October-February } \\
\text { October-February } \\
\text { December-March }\end{array}$ & $\begin{array}{l}I \\
I \\
I \\
U\end{array}$ & $\begin{array}{r}2489 \cdot 0 \\
297 \cdot 5 \\
1554 \cdot 7 \\
636 \cdot 8\end{array}$ & $\begin{aligned} C I & =2.0 \\
I I & =1 \cdot 74\end{aligned}$ \\
\hline \multicolumn{5}{|c|}{ Diversion from $K R S$ reservoir } \\
\hline $\begin{array}{l}\text { Mulberry } \\
\text { Groundnut } \\
\text { Ragi/jowar } \\
\text { Rice }\end{array}$ & $\begin{array}{l}\text { Perennial } \\
\text { June-October } \\
\text { January-April } \\
\text { June-November }\end{array}$ & $\begin{array}{l}I \\
I \\
I \\
U\end{array}$ & $\begin{array}{l}207 \cdot 0^{*} \\
214 \cdot 8 \\
572 \cdot 0 \\
357 \cdot 2\end{array}$ & $\begin{array}{l}C I=1.73 \\
I I=1.28\end{array}$ \\
\hline \multicolumn{5}{|c|}{ Diversion from Kabini reservoir } \\
\hline $\begin{array}{l}\text { Rice } \\
\text { Ragi/jowar } \\
\text { Wheat }\end{array}$ & $\begin{array}{l}\text { June-November } \\
\text { January-April } \\
\text { November-March }\end{array}$ & $\begin{array}{l}I \\
I \\
U\end{array}$ & $\begin{array}{l}878 \cdot 0 \\
447.6 \\
430 \cdot 4\end{array}$ & $\begin{array}{l}C I=2.0 \\
I I=1.51\end{array}$ \\
\hline
\end{tabular}

$I=$ irrigated, $U=$ unirrigated; $C I=$ cropping intensity; $I I=$ irrigation intensity; * Fixed value 
Table 18. Solution for maximum net benefits*-case $4 N N$

Maximum net benefits $=R s 2.1 \times 10^{3}$ million; Total diversion $=4365.9 \mathrm{~m} \mathrm{cu} \mathrm{m}$; Total irrigated cropped area $=621,860$ ha.

\begin{tabular}{|c|c|c|c|c|}
\hline Crop & Season & $I / U$ & $\begin{array}{l}\text { opped area } \\
\text { (100 ha) }\end{array}$ & \\
\hline \multicolumn{5}{|c|}{ Diversion from reservoir $A$} \\
\hline Rice & June-November & $I$ & $1244 \cdot 5$ & \\
\hline Ragi/jowar & June-October & $I$ & $1244 \cdot 5$ & $C I=2.0$ \\
\hline Soybeans & November-February & $I$ & $981 \cdot 1$ & $I I=1 \cdot 39$ \\
\hline Potato & December-March & $U$ & 1507.9 & \\
\hline \multicolumn{5}{|c|}{ Diversion from reservoir $B$} \\
\hline Mulberry & Perennial & $l$ & $207 \cdot 0$ & \\
\hline Rice & June-November & $I$ & $572 \cdot 0$ & $C l=1.73$ \\
\hline Soybeans & November-February & $I$ & $572 \cdot 0$ & $I I=1 \cdot 73$ \\
\hline \multicolumn{5}{|c|}{ Diversion from reservoir $C$} \\
\hline Rice & June-November & $I$ & $878 \cdot 0$ & \\
\hline Soybeans & December-March & $I$ & $519 \cdot 5$ & $C I=2.00$ \\
\hline Potato & November-February & $U$ & $358 \cdot 5$ & $I I=1.59$ \\
\hline
\end{tabular}

* Exclusive of mulberry cropping fixed at 20,700 ha, $I=$ irrigated, $U=$ unirrigated; $C I=$ cropping intensity; $I=$ irrigation intensity.

Table 19. Solution for maximum irrigated cropped area-case 4NI

Maximum irrigated cropped area $=756,680 \mathrm{ha}$; Total diversions $=4,516.8 \mathrm{~m} \mathrm{cu} \mathrm{m}$; Total net benefits $=$ Rs $1.8 \times 10^{3}$ million.

\begin{tabular}{|c|c|c|c|c|}
\hline Crop & Season & $I / U$ & $\begin{array}{l}\text { Cropped area } \\
\text { (100 ha) }\end{array}$ & \\
\hline \multicolumn{5}{|c|}{ Diversion from reservoir $A$} \\
\hline Rice & June-November & $I$ & $259 \cdot 1$ & \\
\hline Ragi/jowar & June-October & $I$ & $1478 \cdot 6$ & $C I=2 \cdot 0$ \\
\hline Maize & June October & $I$ & $751 \cdot 3$ & $\Pi I=1.79$ \\
\hline Wheat & October-February & $I$ & $1970 \cdot 8$ & \\
\hline Potato & December-March & $U$ & $518 \cdot 2$ & \\
\hline \multicolumn{5}{|c|}{ Diversion from reservoir $B$} \\
\hline Mulberry & Perennial & $I$ & $207 \cdot 0^{*}$ & \\
\hline Rice & June-November & $I$ & $572 \cdot 0$ & $C I=1.73$ \\
\hline Ragi/jowar & January-April & $I$ & $572 \cdot 0$ & $I I=1.73$ \\
\hline \multicolumn{5}{|c|}{ Diversion from reservoir $C$} \\
\hline Rice & June-November & $I$ & $878 \cdot 0$ & \\
\hline Wheat & November-March & $I$ & $495 \cdot 6$ & $C I=2 \cdot 0$ \\
\hline Vegetables/pulses & November-March & $I$ & $300 \cdot 1$ & $I I=2 \cdot 0$ \\
\hline Ragi/jowar & January-April & $I$ & $82 \cdot 3$ & \\
\hline
\end{tabular}

$I=$ irrigated, $U=$ unirrigated; $C I=$ cropping intensity, $I I=$ irrigation intensity; ${ }^{*}$ Value fixed in model. 
Table 20. Solution for maximum total diversion-case 4ND

Maximum reservoir diversions $=4767.3 \mathrm{~m} \mathrm{cu} \mathrm{m}$; Total irrigated cropped area $=688,900 \mathrm{ha}$; Total net benefits $=$ Rs $2.0 \times 10^{3}$ million.

\begin{tabular}{|c|c|c|c|c|}
\hline Crop & Season & $I / U$ & $\begin{array}{l}\text { ropped area } \\
(100 \text { ha) }\end{array}$ & \\
\hline \multicolumn{5}{|c|}{ Diversion from reservoir $A$} \\
\hline Rice & June-November & $I$ & $811 \cdot 7$ & \\
\hline Maize & June-October & $I$ & $1677 \cdot 3$ & \\
\hline Maize & October-February & $I$ & $608 \cdot 7$ & $C I=2 \cdot 0$ \\
\hline Wheat & October-February & $I$ & $256 \cdot 9$ & $I I=1.58$ \\
\hline Soybeans & November-February & $I$ & 573.9 & \\
\hline Potato & December-March & $U$ & $1049 \cdot 5$ & \\
\hline \multicolumn{5}{|c|}{ Diversion from reservoir $B$} \\
\hline Mulberry & Perennial & $I$ & $207 \cdot 0^{*}$ & \\
\hline Rice & June-November & $I$ & $572 \cdot 0$ & $C I=1.73$ \\
\hline Ragi/jowar & January-April & $I$ & $572 \cdot 0$ & $I I=1.73$ \\
\hline \multicolumn{5}{|c|}{ Diversion from reservoir $C$} \\
\hline Rice & June-November & $I$ & $878 \cdot 0$ & \\
\hline Potato & November-February & $I$ & $376 \cdot 4$ & $C I=2 \cdot 0$ \\
\hline Ragi/jowar & January-April & $I$ & 346.9 & $I I=1.82$ \\
\hline Potato & November-February & $U$ & $154 \cdot 7$ & \\
\hline
\end{tabular}

$I=$ irrigated, $U=$ unirrigated; $C I=$ cropping intensity; $I I=$ irrigation intensity; *Value fixed in model.

Table 21. Solution for maximum net benefits*-case $3 Y N$.

Maximum net benefits $=\mathbf{R s ~} 2.2 \times 10^{3}$ million; Total irrigated cropped area $=447,722 \mathrm{ha}$; Total diversion $=1826.5 \mathrm{~m} \mathrm{cu} \mathrm{m}$.

\begin{tabular}{|c|c|c|c|c|}
\hline Crop & Season & \multicolumn{3}{|c|}{$\begin{array}{l}\text { Cropped area } \\
\text { (100 ha) }\end{array}$} \\
\hline \multicolumn{5}{|c|}{ Diversion from reservoir $A$} \\
\hline $\begin{array}{l}\text { Ragi/jowar } \\
\text { Potato }\end{array}$ & $\begin{array}{l}\text { June-October } \\
\text { December-May }\end{array}$ & $\begin{array}{l}I \\
U\end{array}$ & $\begin{array}{l}2489 \cdot 0 \\
2489 \cdot 0\end{array}$ & $\begin{array}{l}C I=2 \cdot 0 \\
I I=1 \cdot 0\end{array}$ \\
\hline \multicolumn{5}{|c|}{ Diversion from reservoir $B$} \\
\hline $\begin{array}{l}\text { Mulberry } \\
\text { Ragi/jowar } \\
\text { Ragi/jowar } \\
\text { Ragi/jowar }\end{array}$ & $\begin{array}{l}\text { Perennial } \\
\text { June-October } \\
\text { January-April } \\
\text { January-April }\end{array}$ & $\begin{array}{l}I \\
I \\
I \\
U\end{array}$ & $\begin{array}{l}207 \cdot 0 \\
572 \cdot 0 \\
331 \cdot 2 \\
240 \cdot 8\end{array}$ & $\begin{array}{l}C I=1.73 \\
I I=1.43\end{array}$ \\
\hline \multicolumn{5}{|c|}{ Diversion from reservoir $C$} \\
\hline $\begin{array}{l}\text { Jowar } \\
\text { Potato }\end{array}$ & $\begin{array}{l}\text { June-October } \\
\text { November-February }\end{array}$ & $\begin{array}{l}I \\
U\end{array}$ & $\begin{array}{l}878 \cdot 0 \\
878 \cdot 0\end{array}$ & $\begin{array}{l}C I=2 \cdot 0 \\
I I=1 \cdot 0\end{array}$ \\
\hline
\end{tabular}

* Exclusive of mulberry cropping fixed at $20,700 \mathrm{ha} ; I=$ irrigated, $U=$ unirrigated; $C I=$ cropping intensity; $I I=$ irrigation intensity. 
Table 22. Solution for maximum irrigated cropped area-case $3 Y I$.

Maximum irrigated cropped area $=578,910 \mathrm{ha}$; Total deversion $=2136.5 \mathrm{~m}$ cu $\mathrm{m}$; Total net benefits $=\mathbf{R s} 1.6 \times 10^{3}$ million

\begin{tabular}{|c|c|c|c|c|}
\hline Crop & Season & $I / U$ & \multicolumn{2}{|c|}{$\begin{array}{l}\text { Cropped area } \\
\quad(100 \text { ha })\end{array}$} \\
\hline \multicolumn{5}{|c|}{ Diversion from reservoir $A$} \\
\hline Maize & June-October & $I$ & $2489 \cdot 0$ & \\
\hline Pulses/vegetables & August-December & $I$ & $193 \cdot 1$ & $C I=20$ \\
\hline Potato & December-March & $U$ & $2295 \cdot 9$ & $I I=1.08$ \\
\hline \multicolumn{5}{|c|}{ Diversion from reservoir $B$} \\
\hline Mulberry & Perennial & $I$ & $207 \cdot 0^{*}$ & $C I=1 \cdot 73$ \\
\hline Ragi/jowar & June--October & $I$ & $572 \cdot 0$ & $I I=1 \cdot 73$ \\
\hline Pulses/vegetables & November-Febraury & $I$ & $572 \cdot 0$ & \\
\hline \multicolumn{5}{|c|}{ Diversion from reservoir $C$} \\
\hline Potato & June-September & $I$ & $878 \cdot 0$ & $C I=2 \cdot 0$ \\
\hline Vegetables & November-March & $I$ & $878 \cdot 0$ & $I I=2 \cdot 0$ \\
\hline
\end{tabular}

* Fixed, excluded in computing net benefits; $I=$ irrigated, $U$ = unirrigated; $C I=$ cropping intensity; $I I=$ irrigation intensity.

Table 23. Solution for maximum diversion - case $3 Y D$.

Maximum diversion $=2277.1 \mathrm{mcum}$; Total irrigated cropped area $=444,012 \mathrm{ha}$; Total net benefits $=\mathrm{Rs} 1.8 \times 10^{3}$ million.

\begin{tabular}{lcc}
\hline Crop Season & $I / U$ & $\begin{array}{c}\text { Cropped area } \\
(100 \mathrm{ha})\end{array}$ \\
\hline
\end{tabular}

Diversion from reservoir $A$

$\begin{array}{lllll}\text { Maize } & \text { June-October } & I & 2489.0 & C I=2.0 \\ \text { Potato } & \text { December-March } & U & 2489.0 & I I=1.0\end{array}$

Diversion from reservoir $B$

$\begin{array}{lllll}\text { Mulberry } & \text { Perennial } & I & 207.0 * & C I=1.73 \\ \text { Ragi/jowar } & \text { January-April } & I & 572.0 & I I=1.00 \\ \text { Ragi/jowar } & \text { June-October } & U & 572.0 & \end{array}$

Diversion from reservoir $C$

\begin{tabular}{lllrl} 
Maize & June-October & $I$ & 851.5 & $C I=2.0$ \\
Ragi/jowar & June-October & $I$ & 320.6 & $I I=1.33$ \\
Rice & June-November & $U$ & 26.5 & \\
Wheat & November-March & $U$ & 557.4 & \\
\hline
\end{tabular}

* Fixed, excluded in computing net benefits; $I=$ irrigated, $U=$ unirrigated; $C I=$ cropping intensity; $I I=$ irrigation intensity.

account above the KRS reservoir including those on the tributaries. In other words, this solution gives the optimum cropping patterns at each of the reservoirs $A, B$ and $C$, which maximizes the total net benefits. The maximum net benefit from table 15 is Rs $2 \cdot 1$ $\times 10^{3}$ million and the corresponding irrigated cropped area is 527,570 ha, while the maximum irrigated cropped area possible is 755,600 ha (table 16), which reduces the net benefit to Rs $1.7 \times 10^{3}$ million. Table 17 gives the results of the same case but for the 
Table 24. Solution for maximum net benefits-case $3 N N$.

Maximum net benefits $=R s 2.3 \times 10^{3}$ million; Total irrigated cropped area $=537,896 \mathrm{ha}$; Total diversion $=2636.9 \mathrm{~m} \mathrm{cu} \mathrm{m}$.

\begin{tabular}{|c|c|c|c|c|}
\hline Crop & Season & $I / U$ & Cropped area (100 ha) & \\
\hline \multicolumn{5}{|c|}{ Diversion from reservoir $A$} \\
\hline Ragi/jowar & June-October & $I$ & 2448.5 & $C I=2 \cdot 0$ \\
\hline Ragi/jowar & August-December & $I$ & $40 \cdot 5$ & $I I=1 \cdot 0$ \\
\hline Potato & December-March & $U$ & $2489 \cdot 0$ & \\
\hline \multicolumn{5}{|c|}{ Diversion from reservoir $B$} \\
\hline Mulberry & Perennial & $I$ & $207 \cdot 0^{*}$ & $C I=1.73$ \\
\hline Ragi/jowar & June-October & $I$ & $572 \cdot 0$ & $I I=1.73$ \\
\hline Ragi/jowar & January-April & $I$ & $483 \cdot 4$ & \\
\hline Soybeans & November-February & $I$ & 88.6 & \\
\hline \multicolumn{5}{|c|}{ Diversion from reservoir $C$} \\
\hline Ragi/jowar & June-October & $I$ & $878 \cdot 0$ & $C I=2 \cdot 0$ \\
\hline Jowar & November-February & $I$ & 661.0 & $I I=1.75$ \\
\hline Potato & November-February & $U$ & $217 \cdot 0$ & \\
\hline
\end{tabular}

* Fixed, excluded in computing net benefits; $I=$ irrigated, $U=$ unirrigated; $C I=$ cropping intensity; $I I=$ irrigation intensity.

Table 25. Solution for maximum irrigated cropped area-case $3 N I$.

Maximum irrigated cropped area $=647,795 \mathrm{ha}$; Total diversion $=2557.2 \mathrm{~m} \mathrm{cu} \mathrm{m}$; Total net benefits $=R s 1.9 \times 10^{3}$ million.

\begin{tabular}{llll}
\hline Crop & Season & $I / U$ & Cropped area (100 ha) \\
\hline
\end{tabular}

Diversion from reservoir $A$

$\begin{array}{lllrl}\text { Ragi/jowar } & \text { June-October } & I & 2376.9 & C I=1.65 \\ \text { Maize } & \text { June-October } & I & 112.1 & I I=1.65 \\ \text { Wheat } & \text { October-February } & I & 1607.0 & \end{array}$

Diversion from reservoir $B$

$\begin{array}{lllll}\text { Mulberry } & \text { Perennial } & I & 207.0^{*} & C I=1.73 \\ \text { Ragi/jowar } & \text { June-October } & I & 572.0 & I I=1.73 \\ \text { Pulses/vegetables } & \text { November-February } & I & 572.0 & \end{array}$

Diversion from reservoir $C$

\begin{tabular}{lcccc}
$\begin{array}{l}\text { Ragi/jowar } \\
\text { Vegetables }\end{array}$ & $\begin{array}{c}\text { June-October } \\
\text { November-March }\end{array}$ & $I$ & \multicolumn{1}{c}{$\begin{array}{l}878.0 \\
878.0\end{array}$} & $\begin{array}{l}C I=2.0 \\
I=2.0\end{array}$ \\
\hline $\begin{array}{l}\text { * Fixed, excluded in computing net benefits; } \\
C I=\text { cropping intensity; } I I=\text { irrigation intensity. }\end{array}$ &
\end{tabular}

objective of maximizing the total diversions. The maximum diversions are $3994.1 \mathrm{~m}$ cu $\mathrm{m}$ which yield net benefits of Rs $1.7 \times 10^{3}$ million (all these benefits are at 1970-72 levels). As far as the net benefits are concerned, the results of the case $4 Y D$ are somewhat midway between the cases $4 Y N$ and $4 Y I$.

There is a definite trade-off between the objectives of maximizing net benefits and maximizing the irrigated cropped area. The latter objective brings a larger number of 
Table 26. Solution for maximum diversions-case $3 N D$.

Maximum diversion $=3158.5 \mathrm{mcum}$; Total irrigated cropped area $=537,561 \mathrm{ha}$; Total net benefits $=\mathbf{R s} 1.9 \times 10^{3}$ million.

\begin{tabular}{|c|c|c|c|c|}
\hline Crop & Season & $I / U$ & \multicolumn{2}{|c|}{ Cropped area (100 ha) } \\
\hline \multicolumn{5}{|c|}{ Diversion from reservoir $A$} \\
\hline Rice & June-November & $I$ & $71 \cdot 0$ & \\
\hline Maize & June October & $I$ & $2418 \cdot 0$ & $C I=2 \cdot 0$ \\
\hline Maize & October-February & $I$ & $281 \cdot 1$ & $I I=1 \cdot 11$ \\
\hline Potato & December-March & $U$ & $2207-9$ & \\
\hline \multicolumn{5}{|c|}{ Diversion from reservoir $B$} \\
\hline Mulberry & Perennial & $I$ & $207 \cdot 0^{*}$ & $C I=1.73$ \\
\hline Rice & June-November & $I$ & $572 \cdot 0$ & $I I=1.73$ \\
\hline Ragi/jowar & January-April & $I$ & $572 \cdot 0$ & \\
\hline \multicolumn{5}{|c|}{ Diversion from reservoir $C$} \\
\hline Rice & June-November & $I$ & $878 \cdot 0$ & $C I=2 \cdot 0$ \\
\hline Soybeans & December-March & $I$ & $376 \cdot 5$ & $I I=1.43$ \\
\hline Wheat & November-March & $U$ & $501 \cdot 5$ & \\
\hline
\end{tabular}

less water intensive crops into the solution than the former. In this case, rice and soybeans are reduced or replaced by crops requiring less water like ragi, jowar and wheat, vegetables and pulses. The object of maximizing the irrigated cropped area, has been cited (Report of the Irrigation Commission, 1972, Vol. I, p. 112) as one of the goals set by the Irrigation Commission in irrigation planning. This is meant to primarily increase employment and improve the economic base of the areas proposed for development. In this present case, the maximum irrigated cropped area is 755,600 ha, an increase of $43 \%$, and the corresponding benefits are about Rs 1.7 $\times 10^{3}$ million (1970-72 level), a reduction of $20 \%$, compared to the results for the objective of maximizing net benefits. The (total) cropping intensity however remains the same. The net effect of increasing the irrigated cropped area by choosing low water requiring crops on the diversions is that the diversions for maximizing the irrigated cropped area are increased by $2.2 \%$ compared with that for net benefits. The aim of maximizing diversions is to some extent complementary to that of maximizing the irrigated cropped area and the results for this are also presented for each case although the objective by itself may not have any practical significance.

The three-reservoir system consisting of the Hemavathy, KRS and Kabini reservoirs is operated such that the releases from the system are adequate to meet the downstream irrigation requirements. In this analysis, the storage at Mettur was not considered. This gives a flexibility of using Mettur storages in lean years. The solutions for this case, again with and without considering upstream developments are given in tables 21,22 , 23 and $24,25,26$ respectively.

\subsection{Trade-off analysis}

As the sole purpose of diversions is assumed to be irrigation, the objectives of maximizing diversions and irrigated cropped area complement each other. However, 


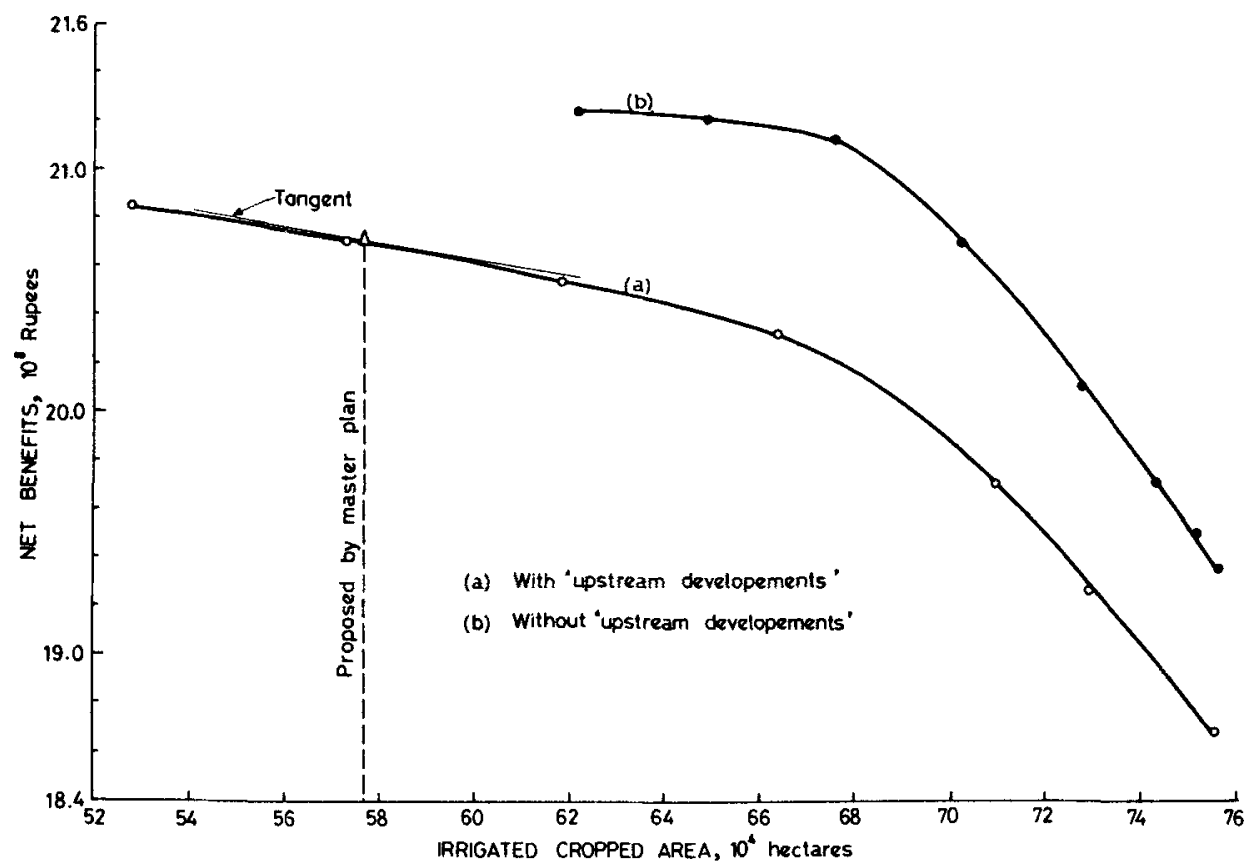

Figure 3. Transformation curves for the four-reservoir system.

the objective of maximizing net benefits is in conflict with either of the other two. Thus, from the point of view of evaluating the trade-offs, it is useful to consider maximizing net income and irrigated cropped area. This is best done by plotting the transformation curve between the irrigated cropped area and the maximum net benefits as in figure 3 . Each of the points plotted in the figure is obtained by maximizing the net benefits for a fixed value of the irrigated cropped area and for each of these points, there exists a solution similar to the one given in table 15.

4.1a Reservoir system with 'upstream developments'-Cases $4 Y N, 4 Y I$ and $4 Y D$ : These cases of the four reservoir system take the upstream developments into account. The solutions for these cases are given in tables 15,16 and 17. The irrigated cropped area is varied between 527,570 ha and the maximum possible value of 755,600 ha to obtain the corresponding net benefits. The values obtained are given below and their plot is shown in figure 3(a)

\begin{tabular}{cc}
$\begin{array}{c}\text { Irrigated cropped area } \\
\text { fixed at (100 ha) }\end{array}$ & $\begin{array}{c}\text { Maximum net benefits } \\
\left(10^{9} \text { Rupees }\right)\end{array}$ \\
\cline { 1 - 1 } 5276 & 2.08 \\
5732 & 2.07 \\
6188 & 2.05 \\
6644 & 2.03 \\
7100 & 1.97 \\
7300 & 1.93 \\
7556 (max) & 1.87
\end{tabular}

Any point on the curve defined by these points is then Pareto admissible. 
The total irrigated cropped area proposed by the Karnataka Master Plan at reservoirs $A, B$ and $C$ is 576,800 ha after considering the rainfall and local conditions. The model shows that the irrigated cropped area can be increased to any value upto 755,600 ha. It should now be interesting to determine the implied trade-off in the proposed value of 576,800 ha by finding the slope of the tangent to the curve plotted in figure 3(a) at the point corresponding to the irrigated cropped area of 576,800 ha. This was found to be Rs 360 of net benefits per hectare of irrigated cropped area.

4.1b Four-reservoir system without upstream developments-Cases $4 N N, 4 N I$ and $4 N D$ : These are the cases of the four-reservoir system without the upstream developments, which aim at maximizing net benefits, irrigated cropped area and total diversions, respectively. The solutions for these three cases are given in tables 18,19 and 20 respectively. The trade-off curve between the net income and the irrigated cropped area is developed for the present case in the same way as in the case with upstream developments. The resulting transformation curve is shown in figure 3(b).

\subsection{Limitations of the study}

The most obvious limitation of the study is that it does not consider the variability of river flows. The model is deterministic with the input consisting of mean monthly values of river flows and evaporation losses. It also does not consider overyear storage. Estimation of crop water requirements is based on general guidelines and assumptions but the actual requirements may vary significantly from place to place depending on the local soil conditions and climatology. Similarly, the farm losses and the conveyance losses to estimate the water diversion requirements from net irrigation requirements may vary from place to place depending on local conditions. In addition, the study carries with it all the limitations of the basic data itself used in various other computations and estimates. Crop yields and net returns for the irrigated and unirrigated crops were estimated based on the data for the whole state, wherever available, and representative values used on consulting available sources of published information (FAO 1975; Government of India 1974).

Another limitation may seem to stem from the argument that the optimum crop patterns obtained from the model may not be acceptable to the farmers. It is emphasized that the present model is a planning model which determines what the optimum or the best cropping pattern should be depending on the objective. Once the possibilities are tested to the limit to see the maximum possible output, the next course of action could be to formulate an operational model to find out how much of this optimum output can actually be realized and in what way.

\section{Concluding remarks}

The application of the techniques of operations research to the study of the upper Cauvery river basin reveals the extent of irrigation potential at the major projects (existing, under construction and proposed) of the basin. The study is based on mean monthly flows and on a linear programming model. Of all the cases considered, the case of the four-reservoir system comprising the Hemavathy, KRS, Kabini and Mettur reservoirs and which considers the proposed developments upstream of the KRS reservoir is the most interesting. The analysis for the trade-off between the objectives of 
maximizing net benefits and irrigated cropped area has been carried out, which reveals the implicit trade-off relationships used in the proposals made by the Karnataka Master Plan.

\section{References}

Dorfman R 1972 in Models for managing regional water quality, (eds) R Dorfman, H D Jacoby, H A Thomas Jr (Harvard: University Press)

FAO 1975 Production Yearbook

Government of India 1965 Evaluation of major irrigation projects-some case studies, Programme Evaluation Organization

Haith D A, Loucks D P 1976 in Systems approach to water management, (ed.) A K Biswas (New York, McGraw Hill)

Hall W A, Dracup J A 1970 Water resources systems engineering, (New York, McGraw Hill)

Irrigation Commission 1972 The Cauvery Basin, Vol. III, Pt. 2, Chap. X, Report, Ministry of Irrigation and Power

Lakshminarayana V, Rajagopalan S P 1977 Irrigation and Drainage, ASCE, March

Master Plan 1976 Master plan for an equitable use of the waters of the Cauvery Basin in Karnataka-an outline in three parts, Government of Karnataka, Water Resources Development Organization

Ministry of Agriculture 1971 A guide for estimating irrigation water requirements, Water Management Division, Ministry of Agriculture, Government of India

Ministry of Agriculture 1974 Estimates of area and production of principal crops in India, 1972-73, Directorate of Economics and Statistics, Ministry of Agriculture, Government of India

National Commission on Agriculture 1976 Report, Part VI Ministry of Agriculture and Irrigation, Government of India

Parikh K J, Srinivasan T N 1974 Optimum requirement of fertilizers for the fifth plan period, Indian Statistical Institute, Planning Unit, New Delhi

Rogers P, Rao P S, Ramaseshan S 1976 Multiobjective analysis for planning and operation of water resource systems: some examples from India, Joint Automatic Control Conference, Purdue University, West Lafayette, Indiana

Rogers P, Smith D 1970 Bulletin of ICID

Sampath R K, Anandalingam G 1976 An interregional programming approach to planning of agricultural production in India, Center for Population Studies, Harvard University, Cambridge, Mass., August

Verma R D 1977 Technology transfer for irrigation planning of arid lands, Seminar paper, Center for Population Studies, Harvard University, Cambridge, Mass.

\section{List of symbols}

$(D D)_{m}=$ minimum release requirement at reservoir $D$ in month $m$

$(E A)_{m},(E B)_{m},(E C)_{m},(E D)_{m}$, = evaporation in month $m$ at reservoirs $A, B, C$ and $D$ respectively.

$(F A)_{m},(F B)_{m},(F C)_{m},(F D)_{m}=$ mean inflows in month $m$ to reservoirs $A, B, C$ and $D$ respectively.

$i, j, k=$ irrigated crop index at reservoir $A, B$ and $C$ respectively.

$(I A)_{i},(I B)_{j},(I C)_{k}=$ irrigated cropped area under crop $i$ at reservoir $A, j$ at $B, k$ at $C$ respectively.

$(I A)_{m, i}=(I A)_{i}$, the irrigated cropped area for the crop $i$ during the growth month $m$ at reservoir $A$; (and similar notations for corresponding symbols in (5), (6), and (7), for reservoirs $B, C$, and $D$, respectively) $=0$, for all other (non-growing) months. 
$(L A),(L B),(L C)=$ total land available under the command of reservoirs $A, B$ and $C$ respectively.

$p_{i}, q_{j}, r_{k}=$ total water diversion requirement of crop $i$ at reservoir $A, j$ at $B$ and $k$ at $C$ respectively.

$p_{m, i}, q_{m, j}, r_{m, k}=$ water diversion requirement for irrigating crop $i$ at reservoir $A, j$ at $B$, and $K$ at $C$ respectively, during the month $m$.

$(R A)_{m},(R B)_{m},(R C)_{m},(R D)_{m}=$ downstream releases from reservoirs $A, B, C$ and $D$ respectively in the month $m$

$(R T)_{m}=$ downstream release from reservoir $D$ in month $m$

$(S A)_{m},(S B)_{m},(S C)_{m},(S D)_{m}=$ storage at the beginning of month $m$ at reservoirs $A, B, C$ and $D$ respectively.

$u, v, w=$ unirrigated crop index at reservoirs $A, B$ and $C$ respectively

$(U A)_{u},(U B)_{v},(U C)_{w}=$ unirrigated cropped area under crop $u$ at reservoir $A, v$ at $B$ and $w$ at $C$, respectively.

$(U A)_{m, u}=(U A)_{m}$, the unirrigated cropped area under crop $u$ during the growing month $m$ (similar notations for corresponding symbols in (9) and (10) for reservoirs $B$ and $C$ respectively) which $=0$, for all other (non-growing) months.

$(W B)_{m},(W D)_{m}=$ water diversion requirements for existing irrigation at reservoirs $B$ and $D$ respectively, during month $m$

$\alpha_{i}, \beta_{j}, \gamma_{k}=$ net benefit per unit area of crops $i, j$ and $k$ respectively.

$\alpha_{w}^{\prime} \beta_{v}^{\prime}, \gamma_{w}^{\prime}=$ net benefit per unit area of crops $u, v$, and $w$ respectively. 